
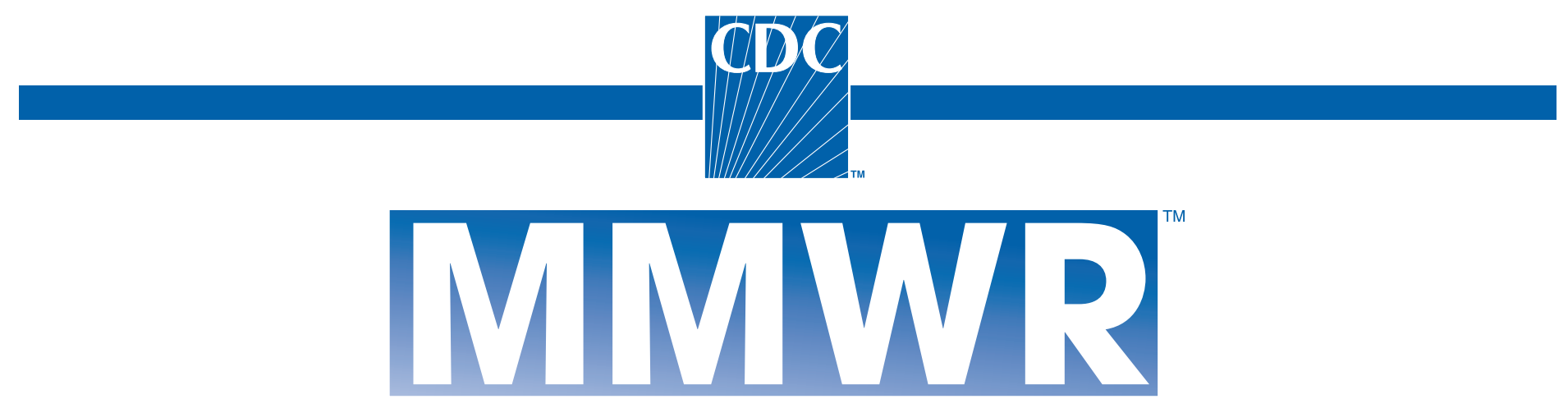

Morbidity and Mortality Weekly Report

Weekly

February 21, 2003 / Vol. 52 / No. 7

\title{
Fatal Degenerative Neurologic Illnesses in Men Who Participated in Wild Game Feasts - Wisconsin, 2002
}

Creutzfeldt-Jakob disease (CJD) is a fatal neurologic disorder in humans. CJD is one of a group of conditions known as transmissible spongiform encephalopathies (TSEs), or prion diseases, that are believed to be caused by abnormally configured, host-encoded prion proteins that accumulate in the central nervous tissue (1). CJD has an annual incidence of approximately 1 case per million population in the United States (1) and occurs in three forms: sporadic, genetically determined, and acquired by infection. In the latter form, the incubation period is measured typically in years. Recent evidence that prion infection can cross the species barrier between humans and cattle has raised increasing public health concerns about the possible transmission to humans of a TSE among deer and elk known as chronic wasting disease (CWD) (2). During 1993-1999, three men who participated in wild game feasts in northern Wisconsin died of degenerative neurologic illnesses. This report documents the investigation of these deaths, which was initiated in August 2002 and which confirmed the death of only one person from CJD. Although no association between CWD and CJD was found, continued surveillance of both diseases remains important to assess the possible risk for CWD transmission to humans.

\section{Case Reports}

Case 1. In December 1992, a Wisconsin man aged 66 years with a history of seizures since 1969 sought treatment for recurring seizures, increasing forgetfulness, and worsening hand tremors. Electroencephalographic (EEG) examination demonstrated focal epileptiform activity and nonspecific diffuse abnormalities, but no specific diagnosis was made. In February 1993, he was hospitalized for increasing confusion, ataxia, and movement tremors of his extremities. A magnetic resonance image (MRI) demonstrated mild, nonspecific enhancement along the inferior parasagittal occipital lobe.
A repeat EEG showed bifrontal intermittent, short-interval, periodic sharp waves, suggesting a progressive encephalopathy; a diagnosis of CJD was suspected. The man died later that month; neuropathologic examination of brain tissue during autopsy indicated subacute spongiform encephalopathy, compatible with CJD.

The man was a lifelong hunter who ate venison frequently. He hunted primarily in northern Wisconsin but also at least once in Montana. He hosted wild game feasts at his cabin in northern Wisconsin from 1976 until shortly before his death. Fixed brain tissue obtained during the autopsy was sent for analysis to the National Prion Disease Pathology Surveillance Center (NPDPSC) and reexamined at the institution where the autopsy was conducted. Histopathologic examination did not substantiate the diagnosis of prion disease. In addition, 27 brain tissue sections were negative for prions by immunostaining despite positive antibody reactions against other proteins (controls), which indicated that other epitopes in the tissue samples were preserved.

Case 2. In May 1999, a Minnesota man aged 55 years with no previous history of a neurologic disease sought evaluation and treatment following a 3-month history of progressive difficulty in writing and unsteadiness of gait. A computerized

\footnotetext{
INSIDE

128 Atrial Fibrillation as a Contributing Cause of Death and Medicare Hospitalization — United States, 1999

131 Potential Exposures to Airborne and Settled Surface Dust in Residential Areas of Lower Manhattan Following the Collapse of the World Trade Center - New York City, November 4-December 11, 2001

136 Smallpox Vaccine Adverse Events Among Civilians United States, January 24-February 18, 2003

136 Notice to Readers
} 
The $M M W R$ series of publications is published by the Epidemiology Program Office, Centers for Disease Control and Prevention (CDC), U.S. Department of Health and Human Services, Atlanta, GA 30333.

\section{SUGGESTED CITATION}

Centers for Disease Control and Prevention. [Article Title]. MMWR 2003;52:[inclusive page numbers].

\section{Centers for Disease Control and Prevention}

Julie L. Gerberding, M.D., M.P.H. Director

David W. Fleming, M.D. Deputy Director for Public Health Science

Dixie E. Snider, Jr., M.D., M.P.H. Associate Director for Science

Epidemiology Program Office

Stephen B. Thacker, M.D., M.Sc.

Director

\section{Office of Scientific and Health Communications}

John W. Ward, M.D.

Director

Editor, MMWR Series

Suzanne M. Hewitt, M.P.A.

Managing Editor, MMWR Series

David C. Johnson

(Acting) Lead Technical Writer/Editor

Jude C. Rutledge

Teresa F. Rutledge

Jeffrey D. Sokolow, M.A.

Writers/Editors

Lynda G. Cupell

Malbea A. Heilman

Visual Information Specialists

Quang M. Doan

Erica R. Shaver

Information Technology Specialists

Division of Public Health Surveillance and Informatics

Notifiable Disease Morbidity and 122 Cities Mortality Data

Robert F. Fagan

Deborah A. Adams

Felicia J. Connor

Lateka Dammond

Patsy A. Hall

Pearl C. Sharp tomography (CT) scan and MRI examination of his head did not indicate any abnormality. In June 1999, he was hospitalized following onset of dementia, speech abnormalities, and myoclonic jerking. An EEG indicated left-hemispheric periodic sharp waves and moderate generalized background slowing; CJD was diagnosed clinically. In July 1999, following worsening symptoms and development of right upper extremity dystonia, the patient died. Neuropathologic evaluation of brain tissue during autopsy demonstrated widespread subcortical spongiform lesions, consistent with CJD.

The man was not a hunter but had a history of eating venison. He made an estimated 12 visits to the cabin where the wild game feasts were held, but he participated in only one feast during the mid-1980s. Sections of fixed and frozen brain tissue obtained during autopsy were analyzed at NPDPSC, and prion disease was confirmed by immunohistochemical and Western blot testing. The Western blot characteristics and prion disease phenotype in this patient were consistent with the most common form of sporadic CJD, classified as M/M $(\mathrm{M} / \mathrm{V}) 1$ (3). Subsequent genetic typing confirmed the presence of methionine homozygosity (M/M) at codon 129 of the patient's prion protein gene.

Case 3. In June 1992, a Wisconsin man aged 65 years sought treatment for progressive slowing of speech, worsening memory, and personality changes. By January 1993, his speech was reduced to one-word utterances. Neurologic examination showed a flat affect, decreased reflexes, and apraxia. A CT head scan showed mild atrophy, and an EEG was normal. Pick's disease was diagnosed. By May, he was unable to perform any daily living activities; he died in August 1993. Neuropathologic evaluation of brain tissue during autopsy showed symmetrical frontal lobe cerebral cortical atrophy and mild temporal lobe atrophy. No Pick's bodies or spongiform lesions were observed.

The man had a history of eating venison and participated regularly in wild game feasts held at the cabin owned by patient 1 . He was a lifelong hunter and hunted mostly in Wisconsin but also in Wyoming and British Columbia. No game was brought to the wild game feasts from his hunting trips outside of Wisconsin. Examination of fixed brain tissue sent to NPDPSC demonstrated no lesions indicative of CJD, and immunohistochemical testing with antibody to the prion protein did not demonstrate the granular deposits seen in prion diseases.

\section{Epidemiologic Investigation}

Wild game feasts consisting of elk, deer, antelope, and other game that occurred at a cabin in northern Wisconsin owned by patient 1 began in 1976 and continued through 2002 . 
These feasts typically involved $10-15$ participants and usually occurred on weekends before or during hunting seasons in the fall and occasionally in the spring. Wild game brought to these feasts usually were harvested in Wisconsin, but three men who attended these feasts reported hunting in the western United States and bringing game back to Wisconsin. These activities took place in Colorado (near the towns of Cortez, Trinidad, Collbran, Durango, and Meeker), Wyoming (near the towns of Gilette and Cody), and Montana (near the town of Malta). CWD was not known to be endemic in these areas at the time that these hunting activities took place.

Information was obtained for $45(85 \%)$ of 53 persons who were identified as possibly participating in the wild game feasts; all were male. Information was obtained by direct interview or from family members of decedents. Of the 45 persons, for whom information was obtained, 34 were reported to have attended wild game feasts. Seven of the 34 feast attendees were deceased, including the three patients. None of the four other decedents had a cause of death attributed to or associated with a degenerative neurologic disorder. None of the living participants had any signs or symptoms consistent with a degenerative neurologic disorder.

Reported by: JP Davis, MD, J Kazmierczak, DVM, MWegner, MD, $R$ Wierzba, Div of Public Health, State of Wisconsin Dept of Health and Family Svcs. P Gambetti, National Prion Disease Pathology Surveillance Center, Case Western Reserve University, Cleveland, Ohio. $L$ Schonberger, MD, R Maddox, MPH, E Belay, MD, Div of Viral and Rickettsial Diseases, National Center for Infectious Diseases; V Hsu, $M D$, EIS Officer, CDC.

Editorial Note: CWD was first described in the United States in the 1960s and classified as a TSE in 1978. Previously localized to a contiguous endemic area in northeastern Colorado and southeast Wyoming, since 2000, CWD has been found in free-ranging deer or elk in Illinois, Nebraska, New Mexico, South Dakota, Wisconsin, and outside the previously known endemic areas of Colorado and Wyoming. CWD has been identified also in captive deer or elk in Colorado, Kansas, Minnesota, Montana, Nebraska, Oklahoma, South Dakota, and Wisconsin (4). Because a variant form of CJD, with specific neuropathologic and molecular characteristics that distinguish it from sporadic CJD, has been associated with eating cattle products infected with a prion that causes bovine spongiform encephalopathy (5), concern has been raised about the possibility that the prion associated with CWD might be transmitted to humans in a similar way.

In this investigation, because only one of the three cases in Wisconsin had neuropathologic confirmation of a prion disease, no association could be made between case participation in the wild game feasts and the development of CJD. Although patient 2 had confirmed CJD, he was unlikely to have eaten CWD-infected venison at these feasts because venison and other game from outside Wisconsin that was served at these feasts did not originate from known CWD-endemic areas, and the man participated in the feasts only once. In addition, the prion disease in this case was consistent with the most common form of sporadic CJD, without apparent unusual neuropathologic or molecular characteristics that might occur if the prion related to CWD had been responsible for the disease.

The findings in this report are subject to at least two limitations. First, not all members participating in wild game feasts could be identified, and not all persons listed as participating could be contacted for interviews. Second, interviews that were conducted required recall of events that occurred up to 25 years ago, limiting the detail or accuracy of events. However, the similar responses obtained from different sources support the accuracy of the investigation findings.

A previous investigation of unusually young CJD patients in whom the transmission of CWD was suspected also did not provide convincing evidence for a causal relationship between CWD and CJD (2). However, limited epidemiologic investigations cannot rule out the possibility that CWD might play a role in causing human illness. Ongoing surveillance of CJD, particularly in states with CWD, is important to assess the risk, if any, for CWD transmission to humans. Because the confirmation of CJD and the detection of a new prion disease require neuropathologic study of brain tissue, physicians are encouraged to contact NPDPSC (http:// www.cjdsurveillance.com; telephone, 216-368-0587) to confirm diagnoses of CJD and to distinguish its various subtypes. Because of the known severity of TSEs in humans and the possibility that the CWD prion can affect humans, animals with evidence of CWD should be excluded from the human food or animal feed chains. Hunters and wild venison consumers should follow precautionary guidelines available from the Wisconsin Department of Agriculture, Trade, and Consumer Protection (http://datcp.state.wi.us/core/consumerinfo) to prevent potential exposures to the CWD agent.

\section{References}

1. Belay E. Transmissible spongiform encephalopathies in humans. Annu Rev Microbiol 1999;53:283-314.

2. Belay E, Gambetti P, Schonberger L, et al. Creutzfeldt-Jakob disease in unusually young patients who consumed venison. Arch Neurol 2001;58:1673-8.

3. Parchi P, Giese A, Capellari S, et al. Classification of sporadic CreutzfeldtJakob disease based on molecular and phenotypic analysis of 300 subjects. Ann Neurol 1999;46:224-33.

4. U.S. Department of Agriculture. Positive CWD cases: cumulative through Dec 2002 (including farm herds already depopulated). Available at http://aphisweb.aphis.usda.gov/vs/nahps//cwd/USAMapOf InfectedHerds.jpg.

5. Will RG, Ironside JW, Zeidler M, et al. A new variant of CreutzfeldtJakob disease in the UK. Lancet 1996;347:921-5. 
Public Health and Aging

\section{Atrial Fibrillation as a Contributing Cause of Death and Medicare Hospitalization — United States, 1999}

Stroke is the leading cause in the United States of serious long-term disability and the third leading cause of death. One of the major risk factors for stroke is atrial fibrillation (AF), a common cardiac disorder characterized by cardiac arrhythmia and the absence of coordinated contractions, which increases the risk for blood stasis, clot formation, and embolic stroke. AF affects approximately 2.2 million adults in the United States $(1,2)$ and is the most common sustained heart rhythm disturbance observed in clinical practice (3). The rate of AF increases with age, from $<1 \%$ among persons aged $<60$ years to approximately $10 \%$ among persons aged $\geq 80$ years (4). The frequency with which AF is reported on death certificates as a contributing cause of death has increased since 1980 (5). To assess the burden of AF-related deaths and hospitalizations among U.S. residents, CDC analyzed national and state multiple-cause mortality statistics and Medicare hospital claims for persons with AF in 1999 (the latest year for which data were available) for the 50 states and the District of Columbia. The findings indicate that $\mathrm{AF}$ as a contributing cause of death and hospitalization affects primarily persons aged $\geq 75$ years and that death and hospitalization rates vary by state. Public and medical education are needed to prevent and reduce AF-related disability and death.

National and state multiple-cause mortality statistics were obtained from death certificates in state vital statistics offices and compiled by CDC. AF-related deaths are those for which the contributing cause of death* (any one of the 20 possible conditions listed on the death certificate) listed by a physician or a coroner is classified as code I48 according to the International Classification of Diseases, Tenth Revision (ICD10). Among decedents who had AF, the proportion of those who had an underlying cause of death listed as AF (ICD-10 I48), coronary heart disease (ICD-10 I20-I25), or stroke (ICD-10 I60-I69) also was assessed. Demographic data (age, sex, and race/ethnicity) on death certificates were reported by funeral directors or provided by family members of the decedent. The denominators for death rates were obtained from 1999 census records and included only U.S. residents.

Medicare (Part A) hospital claims and enrollment records from the Medicare Provider Analysis and Review files were obtained from the Centers for Medicare and Medicaid Services.

\footnotetext{
${ }^{*}$ Contributing cause of death was defined as the subsequent diagnosis considered with the cause of death, and underlying cause of death was defined as the primary diagnosis associated with the death.
}

AF-related hospitalizations among Medicare enrollees aged $\geq 65$ years were classified as code 427.3 according to the International Classification of Diseases, Ninth Revision, Clinical Modification (ICD-9-CM) as one of six diagnoses on the hospital claims during 1999. The denominators for hospitalization rates were obtained from Medicare enrollment records and included enrollees aged $\geq 65$ years who were entitled to Medicare Part A benefits on July 1, 1999 (excluding 15.7\% of members with coverage from health maintenance organizations). Among persons hospitalized with AF, the proportion of those who had a primary hospital diagnosis of AF (ICD-9 427.3), coronary heart disease (ICD-9 410-414, 429.2), or stroke (ICD-9 430-434, 436-438) also was assessed.

AF-related death rates for groups defined by age, sex, race/ ethnicity, and state were determined by dividing the number of deaths by the population at risk (denominator) in each group. Rates of hospitalizations among Medicare enrollees aged $\geq 65$ years with AF for each group were determined by dividing the number of hospitalizations by the population at risk (denominator) in the group. Age-adjusted death rates (per 100,000 population) and hospitalization rates (per 1,000 Medicare enrollees) were calculated by using the 2000 U.S. standard population $(6)$.

In 1999 , a total of 66,875 deaths with $\mathrm{AF}$ as a contributing cause occurred, resulting in an age-adjusted death rate of 24.7 per 100,000 population. Of these deaths, 56,138 (84.0\%) were among persons aged $\geq 75$ years. The greatest proportion of these AF-related deaths occurred among persons aged $\geq 85$ years $(47.4 \%)$, followed by those aged $75-84$ years $(36.6 \%)$, aged $65-74$ years $(12.3 \%)$, and aged $<65$ years $(3.7 \%)$. Agespecific death rates increased for successive age groups (Table 1 ). Age-adjusted death rates for AF were highest among whites (25.7) and blacks (16.4) and higher for men (34.7) than women (22.8). In 1999, for all decedents who had AF, the most common underlying causes of death were coronary heart disease (28.0\%), AF (12.4\%), and stroke (10.8\%).

In 1999 , a total of $1,765,304$ hospitalizations (137.1 per 1,000 Medicare enrollees) were reported among persons with AF in the Medicare population (Table 1). Rates increased among successive age groups. The rate of hospitalization among persons with AF was higher among whites (142.7) than among blacks (100.4). Although $55.7 \%$ of these hospitalizations were among women, men (162.9) had a higher rate of AF-related hospitalization than women (121.2). The most common diseases listed as the primary diagnosis for persons hospitalized with AF were congestive heart failure $(11.8 \%)$, followed by AF (10.9\%), coronary heart disease (9.9\%), and stroke (4.9\%). 


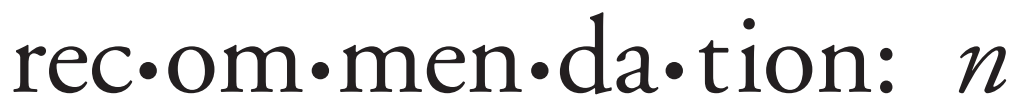

(rek-ə-mən-'dā-shən) 1 : something, such as a course of action, that is recommended; see also $M M W R$.

know what matters.

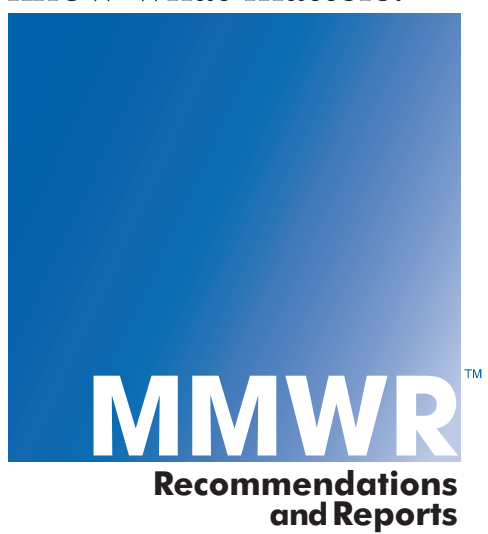


TABLE 1. Number of deaths, age-specific and -adjusted death rates $^{\star}$, and number and rate ${ }^{\dagger}$ of Medicare hospitalizations $\$$ among persons who had atrial fibrillation (AF) ${ }^{11}$ listed as a contributing cause/diagnosis, by selected characteristics United States, 1999

\begin{tabular}{|c|c|c|c|c|}
\hline \multirow[b]{2}{*}{ Characteristic } & \multicolumn{2}{|c|}{ Deaths } & \multicolumn{2}{|c|}{ Hospitalizations } \\
\hline & No. & Rate & No. & Rate \\
\hline \multicolumn{5}{|l|}{ Age-specific } \\
\hline \multicolumn{5}{|l|}{ Age group (yrs) } \\
\hline $0-44$ & 162 & 0.1 & - & - \\
\hline $45-64$ & 533 & 1.5 & - & - \\
\hline $55-64$ & 1,816 & 7.8 & - & - \\
\hline $65-74$ & 8,225 & 45.1 & 458,835 & 33.4 \\
\hline $75-84$ & 24,464 & 201.4 & 788,824 & 83.7 \\
\hline$\geq 85$ & 31,674 & 758.6 & 517,645 & 149.4 \\
\hline \multicolumn{5}{|l|}{ Age-adjusted } \\
\hline \multicolumn{5}{|l|}{ Race } \\
\hline White & 62,415 & 25.7 & $1,614,798$ & 142.7 \\
\hline Black & 3,565 & 16.4 & 98,183 & 100.4 \\
\hline \multicolumn{5}{|l|}{ American Indian/ } \\
\hline Alaska Native & 135 & 10.7 & $一^{* *}$ & -** \\
\hline Asian/Pacific Islander & 760 & 14.1 & 一未* $^{\star *}$ & -** \\
\hline \multicolumn{5}{|l|}{ Ethnicity } \\
\hline Hispanic & 1,397 & 10.5 & —§§ & —§§ \\
\hline Non-Hispanic ${ }^{\dagger \dagger}$ & 65,324 & 25.4 & —§§ & —§§ \\
\hline \multicolumn{5}{|l|}{ Sex } \\
\hline Men & 27,179 & 34.7 & 782,401 & 162.9 \\
\hline Women & 39,696 & 22.8 & 982,903 & 121.2 \\
\hline Total & 66,875 & 24.7 & $1,765,304$ & 137.1 \\
\hline
\end{tabular}

* Per 100,000 population. Age-specific and -adjusted death rates were standardized to the 2000 U.S. population. One non-Hispanic white female decedent whose age was unknown was excluded.

$\dagger$ Per 1,000 enrollees. Age-adjusted rates were standardized to the 2000 U.S. population.

$\S$ Medicare hospital claims data are for persons aged $\geq 65$ years.

"I International Classification of Diseases, Tenth Revision (ICD-10) code 148 for 1999 mortality data. International Classification of Diseases, Ninth Revision, Clinical Modification (ICD-9-CM) code 427.3 for 1999 Medicare data.

** Medicare hospital claims data for Asians/Pacific Islanders and American Indians/Alaska Natives were too small for reliable estimates.

${ }^{\dagger \dagger}$ Excludes 154 AF-related deaths for which ethnicity was not stated.

$\S \S$ Ethnicity was not available for Medicare claims.

The state-specific age-adjusted death rates for AF ranged from 13.1 in Arizona to 37.4 in Maryland (Figure). The ageadjusted rate of hospitalizations among persons with $\mathrm{AF}$ ranged from 90.2 in New Mexico to 177.5 in West Virginia (Table 2).

Reported by: C Ayala, PhD, WA Wattigney, MS, JB Croft, PhD, A Hyduk, MPH, GA Mensah, MD, Div of Adult and Community Health, National Center for Chronic Disease Prevention and Health Promotion; H Davis, PhD, EIS Officer, CDC.

Editorial Note: The findings in this report confirm that AF is a contributing cause of death among older persons, particularly those aged $\geq 75$ years, and that state-specific AF-related death rates vary. These findings are consistent with other trends of AF-related deaths (5). Patterns in the rate of AF-related hospitalization among Medicare enrollees are similar to those for death rates. The high proportion of AF-related deaths and hospitalizations occurring among
FIGURE. State-specific age-adjusted death rates ${ }^{\star}$ for persons who had atrial fibrillation as a contributing cause listed on death certificates - United States, 1999

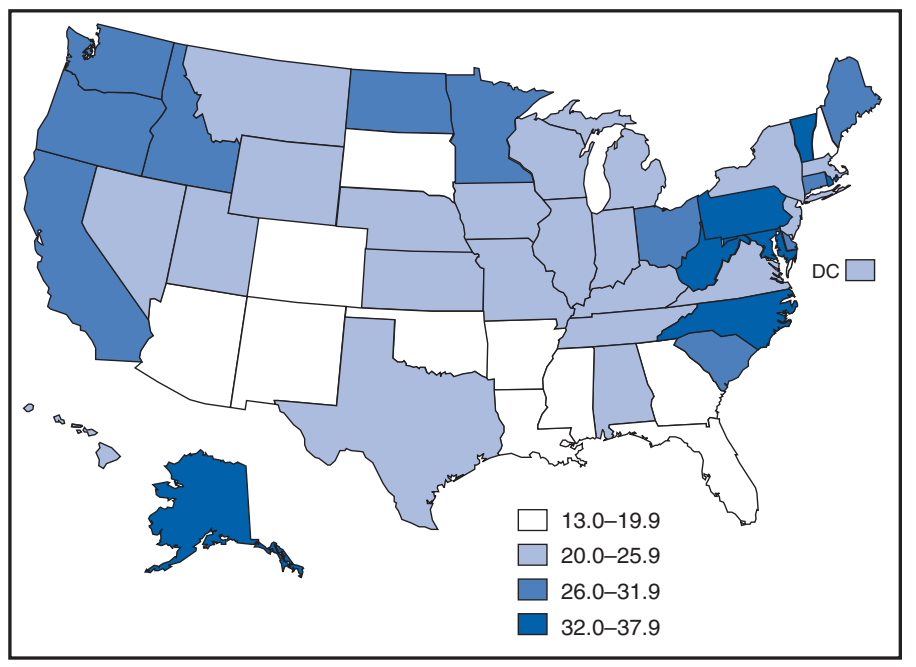

* Per 100,000 population. Age adjusted to the 2000 U.S. population. One decedent in Florida whose age was unknown was excluded from number of deaths.

Source: 1999 multiple-cause mortality data from the National Vital Statistics, National Center for Health Statistics, CDC.

TABLE 2. State-specific number and rate* of Medicare hospitalizations ${ }^{\dagger}$ among persons who had atrial fibrillation ${ }^{\S}$ as a contributing diagnosis listed on Medicare claim - United States, 1999

\begin{tabular}{lrrlrr}
\hline State & No. & Rate & State & No. & Rate \\
\hline Alabama & 38,296 & 162.9 & Montana & 6,680 & 121.9 \\
Alaska & 1,708 & 126.4 & Nebraska & 12,306 & 117.0 \\
Arizona & 18,337 & 115.4 & Nevada & 7,207 & 129.7 \\
Arkansas & 21,090 & 130.8 & New Hampshire & 7,706 & 125.1 \\
California & 113,455 & 131.3 & New Jersey & 67,169 & 157.7 \\
Colorado & 14,559 & 127.8 & New Mexico & 6,200 & 90.2 \\
Connecticut & 24,029 & 134.8 & New York & 121,275 & 139.2 \\
Delaware & 5,756 & 137.9 & North Carolina & 57,756 & 144.4 \\
District of & & & North Dakota & 5,753 & 125.3 \\
Columbia & 2,805 & 99.2 & Ohio & 83,014 & 146.3 \\
Florida & 124,846 & 145.7 & Oklahoma & 23,618 & 126.7 \\
Georgia & 41,264 & 130.0 & Oregon & 16,711 & 137.9 \\
Hawaii & 3,853 & 94.2 & Pennsylvania & 112,123 & 169.2 \\
Idaho & 7,325 & 121.5 & Rhode Island & 7,033 & 146.8 \\
Illinois & 87,206 & 144.2 & South Carolina & 26,524 & 130.1 \\
Indiana & 40,929 & 124.5 & South Dakota & 6,250 & 119.3 \\
lowa & 26,086 & 128.2 & Tennessee & 39,996 & 135.4 \\
Kansas & 18,981 & 119.5 & Texas & 93,399 & 125.5 \\
Kentucky & 31,996 & 152.5 & Utah & 7,855 & 99.3 \\
Louisiana & 27,031 & 144.9 & Vermont & 3,827 & 110.0 \\
Maine & 11,595 & 138.7 & Virginia & 45,262 & 140.5 \\
Maryland & 32,896 & 146.6 & Washington & 26,954 & 124.0 \\
Massachusetts & 47,445 & 157.8 & West Virginia & 20,198 & 177.5 \\
Michigan & 70,317 & 132.4 & Wisconsin & 42,100 & 133.2 \\
Minnesota & 33,355 & 142.8 & Wyoming & 2,817 & 112.2 \\
Mississippi & 20,757 & 135.3 & Total & $\mathbf{1 , 7 6 5 , 3 0 4}$ & $\mathbf{1 3 7 . 1}$ \\
Missouri & 40,333 & 134.7 & & & \\
\hline Z Per & & & &
\end{tabular}

* Per 1,000 enrollees. Age-adjusted rates were calculated based on beneficiary's state of residence and standardized to the 2000 U.S. population.

$\dagger$ Medicare hospital claims data are for persons aged $\geq 65$ years.

$\S$ International Classification of Diseases, Tenth Revision (ICD-10) code 148 for 1999 mortality data. International Classification of Diseases, Ninth Revision, Clinical Modification (ICD-9-CM) code 427.3 for 1999 Medicare data. 
persons aged $\geq 75$ years suggests that as the population ages, AF might be diagnosed more frequently. A cohort study of hospitalized Medicare patients indicated that medical costs were greater for patients with AF than for those without AF (7). In addition, effective therapies for AF reduced the risk for stroke by $\geq 70 \%$. Patients who have coronary heart disease, hypertensive disease, or stroke diagnosed and who live longer might be at risk for AF if effective therapy is not maintained (8). Serious complications among patients with uncontrolled AF also can include congestive heart failure, myocardial infarction, and thrombotic stroke.

Initial treatment of AF should be directed at controlling the ventricular rate with a calcium channel blocker, betablocker, or digitalis (3). Medical or electrical cardioversion to restore sinus rhythm is the next step in patients who remain in AF. Effective therapies in preventing stroke and cardiovascular complications include anticoagulation, heart rate control, conversion of AF to normal heart rhythm, and catheter-based and surgical interventions (3).

Educating the public to recognize the signs of cardiac arrhythmia can help identify persons with AF. Persons can identify an irregular heartbeat by monitoring their wrist pulse for 1 minute. The irregularity of these beats is detected and the next beat cannot be predicted. Persons who identify the signs of cardiac arrhythmia should seek medical care to determine the presence of AF or other heart disorders. The Research Center for Stroke and Heart Disease (http://www. strokeheart.org), has initiated the educational campaign, "Take Your Pulse For Life." This initiative recommends that persons, particularly those aged $\geq 55$ years, monitor their pulse for 1 minute the first day of every month. Assessing whether a patient has $\mathrm{AF}$ can be easy and inexpensive through using electrocardiography (ECG) (3); the availability of more advanced diagnostic tools, such as ECG monitoring, might contribute to AF diagnosis in persons suspected to have cardiac arrhythmia. Delay in diagnosis occurs when the rhythm has not been documented specifically and additional monitoring is necessary (3). All persons should know how to take a pulse for themselves or their family members.

The findings in this report are subject to at least two limitations. First, data are subject to misclassification of race/ ethnicity both in the population census and on death certificates, possibly resulting in overreporting among blacks and whites and underreporting among other racial/ethnic groups (9). Second, it was not possible to determine the accuracy of physician or administrative reporting, the validity of the ICD codes, or multiple hospitalizations on Medicare hospital claims.

Because $\mathrm{AF}$ is one of the major treatable risk factors for stroke, prevention of AF through public and medical education for early identification and appropriate treatment should become an important focus of public health efforts to reduce stroke-related deaths and disability. Prevention efforts should include broad-based public health efforts to increase public awareness of $\mathrm{AF}$ and to foster timely and appropriate diagnostic evaluation and effective treatment from health-care providers.

\section{References}

1. Feinberg WM, Blackshear JL, Laupacis A, Kronmal R, Hart RG. Prevalence, age distribution, and gender of patients with atrial fibrillation. Arch Intern Med 1995;155:469-73.

2. Go AS, Hylek EM, Phillips KA, et al. Prevalence of diagnosed atrial fibrillation in adults: national implications for rhythm management and stroke prevention: the Anticoagulation and Risk Factors in AF (ATRIA) Study. JAMA 2001;285:2370-5.

3. Fuster V, Rydén LE, Asinger RW, et al. ACC/AHA/ESC guidelines for the management of patients with atrial fibrillation: executive summary a report of the American College of Cardiology/American Heart Association Task Force on Practice Guidelines and the European Society of Cardiology Committee for Practice Guidelines and Policy Conferences (Committee to Develop Guidelines for the Management of Patients With Atrial Fibrillation) developed in collaboration with the North American Society of Pacing and Electrophysiology. Circulation 2001;104:2118-50.

4. Ryder KM, Benjamin EJ. Epidemiology and significance of atrial fibrillation. Am J Cardiol 1999;84:131-8.

5. Wattigney WA, Mensah GA, Croft JB. Increased atrial fibrillation mortality: United States, 1980-1998. Am J Epidemiol 2002;155:1-7.

6. Anderson RN, Rosenberg HM. Age standardization of death rates: implementation of the year 2000 standard. Hyattsville, Maryland: U.S. Department of Health and Human Services, CDC, National Center for Health Statistics, 1998; Natl Vital Stat Rep, vol. 47, no. 3.

7. Wolf PA, Mitchell JB, Baker CS, et al. Impact of atrial fibrillation on mortality, stroke, and medical cost. Arch Intern Med 1998;158:229-34.

8. Cooper R, Cutler J, Desvigne-Nickens P, et al. Trends and disparities in coronary heart disease, stroke, and other cardiovascular disease in the United States: findings of the National Conference on Cardiovascular Disease Prevention. Circulation 2000;102:3137-47.

9. Rosenberg HM, Maurer JD, Sorlie PD, et al. Quality of death rates by race and Hispanic origin: a summary of current research, 1999. Vital Health Stat 1999;2:1-12.

\section{Potential Exposures to Airborne and Settled Surface Dust in Residential Areas of Lower Manhattan Following the Collapse of the World Trade Center - New York City, November 4- December 11, 2001}

Following the terrorist attacks of September 11, 2001, which destroyed the World Trade Center (WTC) in lower Manhattan, the New York City (NYC) Department of Health and Mental Hygiene (DOHMH) and the Agency for Toxic Substances and Disease Registry (ATSDR), with assistance from the U.S. Public Health Service (PHS) Commissioned Corps 
Readiness Force* and the WTC Environmental Assessment Working Group ${ }^{\dagger}$, assessed the composition of outdoor and indoor settled surface and airborne dust in residential areas around the WTC and in comparison areas. This report summarizes the results of the investigation, which found 1) similar levels of airborne total fibers in lower and in upper Manhattan, 2) greater percentage levels of synthetic vitreous fibers (SVF) and mineral components of concrete and building wallboard in settled dust of residential areas in lower Manhattan than in upper Manhattan, and 3) low levels of asbestos in some settled surface dust in lower Manhattan residential areas (1). Based in part on the results of this investigation, the U.S. Environmental Protection Agency (EPA) is cleaning and sampling residential areas as requested by lower Manhattan residents. In addition, to assess any short- or longterm health effects of smoke, dust, and airborne substances around the WTC site, DOHMH and ATSDR are developing a registry that will track the health of persons who were most highly exposed to these materials.

During November 4-December 11, 2001, air and settled surface dust samples were collected in and around 30 residential buildings within three concentric circles surrounding the WTC site in lower Manhattan, including 59 residential units (2). In addition, five residential units in four buildings located north of 59th Street (approximately 5 miles northeast of the WTC site) were sampled for purposes of comparison. Attention was focused on building material constituents 1) that have irritant properties (e.g., SVF, including fiberglass and gypsum) or might have negative long-term health effects (e.g., crystalline silica and asbestos) and 2) that were reasonably presumed to be either in the initial WTC collapse dust cloud or in dust generated by subsequent rescue and recovery activities at the WTC site. All samples collected during the investigation were analyzed for the presence of asbestos, SVF, crystalline mineral components of concrete (e.g., silica, calcite, and portlandite), and crystalline mineral components of building wallboard (e.g., gypsum, mica, and halite).

At each sampling location, time-weighted air sampling was conducted for three or four particulate matter (PM) fractions (i.e., PM 100 microns, 10 microns, 4 microns, and 2.5 microns) (3-5). Each PM fraction was analyzed for crystalline minerals by using X-ray diffraction (XRD) analysis ( 6 ).

\footnotetext{
${ }^{*}$ A cadre of PHS Commissioned Corps officers who can be mobilized during disaster, strife, or other public health emergencies and in response to domestic or international requests.

$\dagger$ A group formed on September 15, 2001, that comprises representatives of the U.S. Department of Health and Human Services, Environmental Protection Agency (EPA), Department of Labor, and New York State and NYC government and private organizations to coordinate public health and occupational sampling and data review among the three federal agencies in support of state and city health departments.
}

The XRD analysis for crystalline minerals was semiquantitative (i.e., estimated). Air samples for fibers were analyzed first by phase contrast microscopy (PCM) (5). If the concentration of total fibers was higher than the maximum concentration of fibers found in the comparison homes ( 0.003 fibers per cubic centimeter of air $[\mathrm{f} / \mathrm{cc}])$, the sample was re-analyzed for asbestos fibers by using transmission electron microscopy (TEM) (5). In addition, scanning electron microscopy (SEM) to look for SVF was used for PCM fiber counts $>0.003 \mathrm{f} / \mathrm{cc}$ if the settled surface dust sample from that area contained SVF.

Settled surface dust samples also were taken at each sampling location and analyzed for crystalline minerals and fibers (Figure). Fiber analysis of settled dust samples for asbestos and SVF was conducted by using polarized light microscopy (PLM) (7). If asbestos levels were below the detection limit (i.e., $<1 \%$ ), samples were re-analyzed by using TEM (7). The dust samples also were analyzed for crystalline mineral content by using XRD.

\section{Air Sampling Results}

For $111(94.9 \%)$ of the 117 air samples, the concentrations of fibers found in lower Manhattan residential areas were similar to the concentration of fibers found in comparison areas $(<0.003 \mathrm{f} / \mathrm{cc})$. The six lower Manhattan areas that had elevated total fiber counts were re-examined by TEM and SEM to determine the types of fibers; the results indicated that neither asbestos nor SVF (e.g., fiberglass) contributed to the elevated total fiber counts.

Air sampling results for minerals detected quartz and other building material constituents in lower Manhattan. No other forms of crystalline silica were detected in any air samples except for a one-time detection of cristobalite (15 micrograms per cubic meter $\left.\left[\mu \mathrm{g} / \mathrm{m}^{3}\right]^{\S}\right)$. The estimated concentrations of these minerals in air were low. In some locations, mineral com-

${ }^{\circledR}$ Estimated.

FIGURE. U.S. Public Health Service commissioned officer collecting samples from a previously cleaned interior residential area - New York City, November 2001

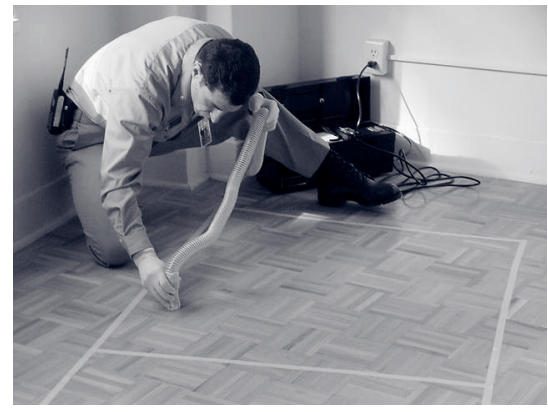

Photo/U.S. Public Health Service 
ponents of concrete (quartz [not detected (ND) $-19 \mu \mathrm{g} / \mathrm{m}^{3 \S}$ ], calcite $\left[\mathrm{ND}-14 \mu \mathrm{g} / \mathrm{m}^{3 \S}\right.$ ], and portlandite [ND-95 $\mu \mathrm{g} / \mathrm{m}^{3 \S}$ ]) and mineral components of building wallboard (gypsum [ND-15 $\mu \mathrm{g} / \mathrm{m}^{3 \$}$ ], mica [ND-43 $\mu \mathrm{g} / \mathrm{m}^{3 \S}$ ], and halite [ND$\left.19 \mu \mathrm{g} / \mathrm{m}^{3 \$}\right]$ ) were detected at higher estimated levels in air samples in lower Manhattan than in samples collected in comparison areas. Gypsum was the only mineral detected in the comparison building air samples (ND-5 $\mu \mathrm{g} / \mathrm{m}^{3 \S}$ ). No other minerals tested (i.e., quartz, calcite, portlandite, mica, and halite) were detected in comparison building air samples.

\section{Settled Surface Dust Results}

In lower Manhattan, asbestos and SVF were found in some indoor settled dust samples from residential units and common areas (Table 1). No asbestos or SVF was detected in the comparison area dust samples. Quartz, calcite, portlandite, and gypsum comprised a higher percentage of the dust in 29 samples from buildings in lower Manhattan compared with eight samples from comparison area buildings (Table 2). Only two $(2.1 \%)$ of the 97 dust samples collected provided enough bulk material for $\mathrm{pH}$ analysis. The samples, which were collected from two outdoor locations in lower Manhattan, had $\mathrm{pH}$ values of 8.6 and 9.8, respectively.
Reported by: NL Jeffery, MPH, C D'Andrea, MS, J Leighton, PhD, New York City Dept of Health and Mental Hygiene, New York. SE Rodenbeck, ScD, L Wilder, CIH, D DeVoney, PhD, S Neurath, PhD, CV Lee, MD, RC Williams, MS, Div of Health Assessment and Consultation, Agency for Toxic Substances and Diseases Registry.

Editorial Note: Exposure to substantial amounts of SVF, mineral components of concrete, and mineral components of building wallboard might cause skin rashes, eye irritation, and upper respiratory irritation, all of which were reported more frequently than expected seasonal rates by community members and first responders after the collapse of the WTC towers $(8-10)$. If the reported irritant effects were associated with WTC-related materials, these effects would subside once exposure to SVF, mineral components of concrete, and mineral components of building wallboard ceased. Persons with pre-existing heart or lung diseases (e.g., asthma) or a previous history of occupational exposure to these materials might be more sensitive to their irritant effects.

Settled surface dust might become airborne if disturbed, potentially causing exposures to occur through inhalation. Several worst-case assumptions were made to assess the potential long-term public health risks for inhaling airborne asbestos and quartz. These assumptions included 1) that no

TABLE 1. Number and percentage of locations with asbestos or synthetic vitreous fibers (SVF) found in settled surface dust, by testing method and sampling location/environment - New York City, November 4-December 11, 2001

\begin{tabular}{|c|c|c|c|c|c|c|c|c|c|}
\hline \multirow{2}{*}{$\begin{array}{l}\text { Sampling location/ } \\
\text { Environment }\end{array}$} & \multicolumn{3}{|c|}{ No. and type of analysis* } & \multicolumn{2}{|c|}{$\begin{array}{c}\text { Locations with } \\
\text { asbestos in settled } \\
\text { surface dust }{ }^{\dagger} \\
\end{array}$} & \multirow{2}{*}{$\begin{array}{c}\text { Range } \\
\text { of asbestos } \\
\text { found } \$\end{array}$} & \multicolumn{2}{|c|}{$\begin{array}{l}\text { Locations with } \\
\text { SVF in settled } \\
\text { surface dust }{ }^{1} \\
\end{array}$} & \multirow{2}{*}{$\begin{array}{l}\text { Range } \\
\text { of SVF } \\
\text { found }^{\star \star}\end{array}$} \\
\hline & No. & Material & Test & No. & (\%) & & No. & $(\%)$ & \\
\hline \multicolumn{10}{|l|}{ Lower Manhattan } \\
\hline Outdoor $(n=14)$ & $\begin{array}{l}14 \\
12 \\
14\end{array}$ & $\begin{array}{l}\text { Asbestos } \\
\text { Asbestos } \\
\text { SVF }\end{array}$ & $\begin{array}{l}\text { PLM } \\
\text { TEM } \\
\text { PLM }\end{array}$ & 6 & (43) & $<1 \%-3.4 \%$ & 11 & (79) & $1 \%-72 \%$ \\
\hline Common $(n=26)$ & $\begin{array}{l}26 \\
25 \\
26\end{array}$ & $\begin{array}{l}\text { Asbestos } \\
\text { Asbestos } \\
\text { SVF }\end{array}$ & $\begin{array}{l}\text { PLM } \\
\text { TEM } \\
\text { PLM }\end{array}$ & 5 & (19) & $<1 \%-1.5 \%$ & 14 & (54) & $5 \%-27 \%$ \\
\hline Residential $(n=57)$ & $\begin{array}{l}57 \\
52 \\
57\end{array}$ & $\begin{array}{l}\text { Asbestos } \\
\text { Asbestos } \\
\text { SVF }\end{array}$ & $\begin{array}{l}\text { PLM } \\
\text { TEM } \\
\text { PLM }\end{array}$ & 10 & (18) & $<1 \%-1.5 \%$ & 26 & $(46)$ & $2 \%-35 \%{ }^{\dagger \dagger}$ \\
\hline Whole building $(n=29)$ & $\begin{array}{l}29 \\
29 \\
29\end{array}$ & $\begin{array}{l}\text { Asbestos } \\
\text { Asbestos } \\
\text { SVF }\end{array}$ & $\begin{array}{l}\text { PLM } \\
\text { TEM } \\
\text { PLM }\end{array}$ & 12 & $(41)$ & $<1 \%-3.4 \%$ & 21 & $(72)$ & $2 \%-72 \%$ \\
\hline \multicolumn{10}{|l|}{ Comparison buildings } \\
\hline Common $(n=3)$ & $\begin{array}{l}3 \\
3 \\
3\end{array}$ & $\begin{array}{l}\text { Asbestos } \\
\text { Asbestos } \\
\text { SVF }\end{array}$ & $\begin{array}{l}\text { PLM } \\
\text { TEM } \\
\text { PLM }\end{array}$ & 0 & 0 & - & 0 & 0 & - \\
\hline Residential $(n=5)$ & $\begin{array}{l}5 \\
4 \\
5\end{array}$ & $\begin{array}{l}\text { Asbestos } \\
\text { Asbestos } \\
\text { SVF }\end{array}$ & $\begin{array}{l}\text { PLM } \\
\text { TEM } \\
\text { PLM }\end{array}$ & 0 & 0 & - & 0 & 0 & - \\
\hline
\end{tabular}

\footnotetext{
* All dust samples were analyzed initially by using polarized light microscopy (PLM); transmission electron microscopy (TEM) analysis was performed to confirm the absence of asbestos if not detected by PLM analysis.

${ }^{\dagger}$ Detected by either PLM or TEM (reported as $<1 \%$ or more); calculated from the total number of dust samples.

$\S$ The highest value detected at a location (PLM or TEM).

" Calculated from the number of SVF PLM samples.

** For some locations, an additional co-located sample was obtained; the range shown considers the highest measured value for each sampling location.

${ }^{\dagger}$ One residential unit had an extra settled surface dust sample, taken from a window sill, which contained $40 \%$ SVF by PLM.
} 
TABLE 2. Number and percentage of locations in which selected mineral components were found in settled surface dust, by sampling location/environment and amount detected — New York City, November 4-December 11, 2001

\begin{tabular}{|c|c|c|c|c|c|c|c|}
\hline \multirow[b]{2}{*}{ Location/Environment } & \multicolumn{2}{|c|}{ Occurrences* } & \multirow{2}{*}{$\begin{array}{c}\text { Minimum } \\
\text { detected } \\
\text { (\% by weight) }\end{array}$} & \multirow{2}{*}{$\begin{array}{c}\text { Maximum } \\
\text { detected } \\
\text { (\% by weight) }\end{array}$} & \multirow{2}{*}{$\begin{array}{c}\text { Average } \\
\text { of detections } \\
\text { (\% by weight) }\end{array}$} & \multicolumn{2}{|c|}{$\begin{array}{c}\text { No. above } \\
\text { comparison }\end{array}$} \\
\hline & No. & $(\%)$ & & & & No. & $(\%)$ \\
\hline \multicolumn{8}{|c|}{ Lower Manhattan } \\
\hline \multicolumn{8}{|c|}{ Outdoor settled surface dust $(n=14)$} \\
\hline Quartz & 14 & $(100)$ & $1.00 \S$ & $27.00 \S$ & $12.00 \S$ & ๆ & \\
\hline Calcite & 13 & $(93)$ & $0.80 \S$ & $19.00 \S$ & $6.00 \S$ & ๆ & \\
\hline Portlandite & 12 & $(86)$ & $0.07 \S$ & $6.00 \S$ & $2.00 \S$ & ๆ & \\
\hline Gypsum & 11 & (79) & $0.03^{\S}$ & $27.00 \S$ & $6.00 \S$ & ๆ & \\
\hline Mica & 9 & (64) & $0.05^{\S}$ & $0.30 \S$ & $0.10^{\S}$ & ๆ & \\
\hline Halite & 7 & (50) & $<0.03 \S$ & $0.10^{\S}$ & $0.05^{\S}$ & ๆ & \\
\hline \multicolumn{8}{|c|}{ Common area settled surface dust $(n=26)$} \\
\hline Quartz & 21 & $(81)$ & $0.03^{\S}$ & $25.00 \S$ & $5.00 \S$ & 6 & (23) \\
\hline Calcite & 15 & (58) & $0.02^{\S}$ & $10.00 \S$ & $3.00^{\S}$ & 9 & (35) \\
\hline Portlandite & 13 & (50) & $0.04^{\S}$ & $4.00^{\S}$ & $2.00 \S$ & 9 & (35) \\
\hline Gypsum & 23 & (88) & $0.07 \S$ & $20.00 \S$ & $5.00 \S$ & 6 & (23) \\
\hline Mica & 5 & (19) & $0.06 \S$ & $0.60 \S$ & $0.20 \S$ & 5 & (19) \\
\hline Halite & 4 & (15) & $0.04 \S$ & $0.06^{\S}$ & $0.05^{\S}$ & 1 & (4) \\
\hline \multicolumn{8}{|c|}{ Residential units settled surface dust $(n=57)$} \\
\hline Quartz & 30 & $(53)$ & $0.05 \S$ & $31.00 \S$ & $9.00 \S$ & 15 & (26) \\
\hline Calcite & 20 & (35) & $0.02^{\S}$ & $21.00 \S$ & $8.00 \S$ & 13 & (23) \\
\hline Portlandite & 21 & (37) & $0.05^{\S}$ & $8.00 \S$ & $2.00 \S$ & 17 & (30) \\
\hline Gypsum & 45 & (79) & $0.05^{\S}$ & $30.00^{\S}$ & $4.00^{\S}$ & 9 & (16) \\
\hline Mica & 5 & (9) & $0.03^{\S}$ & $0.30 \S$ & $0.10^{\S}$ & 1 & (2) \\
\hline Halite & 6 & $(11)$ & $0.03^{\S}$ & $0.10^{\S}$ & $0.06^{\S}$ & 0 & \\
\hline \multicolumn{8}{|c|}{ Comparison areas above 59th Street } \\
\hline \multicolumn{8}{|c|}{ Common areas $(n=3)$} \\
\hline Quartz & 2 & $(67)$ & $1.00 \S$ & $1.00 \S$ & ๆ & & \\
\hline Calcite & 2 & (67) & $0.03^{\S}$ & $0.40^{\S}$ & ๆ & & \\
\hline Portlandite & 1 & (33) & $0.05^{\S}$ & $0.05^{\S}$ & ๆ & & \\
\hline Gypsum & 2 & (67) & $2.00 \S$ & $3.00 \S$ & १ & & \\
\hline Mica & 0 & (0) & - & - & - & & \\
\hline Halite & 1 & (33) & $0.04^{\S}$ & $0.04 \S$ & १ & & \\
\hline \multicolumn{8}{|c|}{ Residential units $(n=5)$} \\
\hline Quartz & 2 & (40) & $1.00 \S$ & $2.00 \S$ & ๆ & & \\
\hline Calcite & 1 & (20) & $0.90^{\S}$ & $0.90^{\S}$ & ๆ & & \\
\hline Portlandite & 2 & (40) & $0.08^{\S}$ & $0.08^{\S}$ & ๆ & & \\
\hline Gypsum & 4 & (80) & $2.00 \S$ & $4.00^{\S}$ & $3.00 \S$ & & \\
\hline Mica & 1 & (20) & $0.08^{\S}$ & $0.08^{\S}$ & ก & & \\
\hline Halite & 1 & (20) & $0.40^{\S}$ & $0.40^{\S}$ & ๆ & & \\
\hline
\end{tabular}

* Locations where a mineral was detected; percentages based on number of samples obtained from an area. Outdoor samples were not taken from comparison areas above 59th Street because no settled surface dust was visible.

$\dagger$ Shows the number of results and the percentage of samples obtained from this area that had estimated values greater than the maximum levels found at locations above 59th Street.

$\S$ Estimated values to one significant digit; presentation of results as shown does not imply any higher degree of accuracy.

१ Not applicable.

cleaning of indoor spaces had occurred or would occur, 2) that all airborne fibers were asbestos, and 3) that the highest levels detected during sampling represented long-term air levels. Under these worst-case conditions, prolonged exposure (i.e., decades) to airborne asbestos and quartz might increase the long-term risk for persons developing lung cancer and other adverse lung health effects (approximately one additional case per 10,000 persons exposed). However, persons who clean their residences frequently as recommended (1) or who participate in the EPA cleaning and sampling program are unlikely to be exposed to worst-case conditions.
The findings of this investigation are subject to at least two limitations. First, the results do not necessarily reflect conditions found in other buildings, the time period immediately after the collapse, or the time period after December 12, when the sampling was completed. Second, a limited number of samples were obtained from comparison areas to determine NYC background levels of asbestos, SVF, mineral components of concrete, and mineral components of building wallboard. The comparison area results might not reflect NYC background levels. 
Following the investigation, DOHMH and ATSDR made three recommendations (1). First, because more asbestos, SVF, mineral components of concrete and building wallboard were found in settled surface dust in lower Manhattan residential areas than in comparison residential areas, residents of lower Manhattan were advised to continue cleaning frequently with high-efficiency particulate air (HEPA) filter vacuums and damp cloths/mops to reduce the potential for exposure. Second, to ensure the effectiveness of the recommended cleaning, DOHMH and ATSDR recommended additional monitoring of residential areas in lower Manhattan and an investigation to define background levels specific to NYC for asbestos, SVF, mineral components of concrete, and mineral components of building wallboard. EPA is implementing this recommendation and conducting this investigation. Finally, lower Manhattan residents concerned about possible WTCrelated dust in their residential areas were advised to request cleaning and testing from EPA no later than December 31, 2002. EPA is conducting the requested cleaning and testing of lower Manhattan residential areas.

DOHMH and ATSDR are developing a registry of those persons who were most highly exposed, including persons living, working, or attending school in lower Manhattan; persons who responded to the emergency; persons working at the WTC site or the Staten Island landfill following the attacks; and persons working in buildings that were damaged or destroyed in the attacks. The registry will track the health of participants to determine whether their exposures to smoke, dust, and airborne substances around the WTC site might have any short- or long-term impacts on their physical health. Additionally, the registry is intended to track the mental health of the approximately 100,000-200,000 persons who might enroll.

\section{References}

1. New York City Department of Health and Mental Hygiene and Agency for Toxic Substances and Disease Registry. Final report of the public health investigation to assess potential exposures to airborne and settled surface dust in residential areas of lower Manhattan. Atlanta, Georgia: U.S. Department of Health and Human Services, Agency for Toxic Substances and Disease Registry, 2002.

2. New York City Department of Health and Mental Hygiene and Agency for Toxic Substances and Disease Registry. Ambient and indoor sampling for public health evaluations of residential areas near World Trade Center, New York, New York: sampling protocol. New York, New York: New York City Department of Health and Mental Hygiene, 2001.

3. American Conference of Governmental Industrial Hygienists. Documentation of TLVs and BEIs, 7th edition. Cincinnati, Ohio: American Conference of Governmental Industrial Hygienists, 2001.

4. U.S. Environmental Protection Agency. National ambient air quality standards for particulate matter; final rule. Federal Register, Part II, 40 CFR Part 50, July 18, 1997.

5. CDC. Manual of analytical methods, 4th edition. Atlanta, Georgia: U.S. Department of Health and Human Services, National Institute for Occupational Safety and Health, CDC, August 1994.

\section{"The wisest mind has something yet to learn."}

\author{
George Santayana
}

\begin{abstract}
MMWR Continuing Education makes it possible for you to stay current on relevant public health and clinical topics-online and at no charge.
\end{abstract}

Review course descriptions, take exams, track your results, and receive course certificatesall from your own computer, when and where your schedule allows.

MMWR CE

A wise choice.

cdc.gov/mmwr

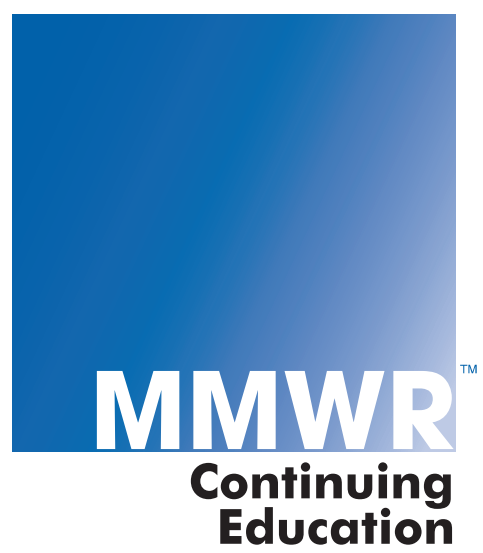


6. EMSL Analytical, Inc. EMSL Laboratory's MSD 0700: operating procedures for the analysis of silica by X-ray diffraction (XRD). Westmont, New Jersey: EMSL Analytical, Inc., January 2000.

7. New York State Department of Health. Environmental Laboratory Approval Program (ELAP) certification manual. Albany, New York: New York State Department of Health, March 1997.

8. CDC. Self-reported increase in asthma severity after the September 11 attacks on the World Trade Center-Manhattan, New York, 2001. MMWR 2002;51:781-4.

9. CDC. Injuries and illnesses among New York City Fire Department rescue workers after responding to the World Trade Center attacks. MMWR 2002;51(Special Issue):1-5.

10. CDC. Community needs assessment of lower Manhattan residents following the World Trade Center attacks - Manhattan, New York City, 2001. MMWR 2002:51(Special Issue):10-3.

\section{Smallpox Vaccine Adverse Events Among Civilians - United States, January 24-February 18, 2003}

During the civilian smallpox vaccination program, CDC and state health departments are conducting surveillance for vaccine-associated adverse events. In the first stage of the program, active surveillance is being conducted for potentially life-threatening, moderate-to-severe, and other serious adverse events and for vaccinia transmission to contacts of vaccinees (1) (Table). Nonserious events are reported via passive surveillance and are expected to be underreported. This report summarizes smallpox vaccine adverse events reported among civilians vaccinated as of February 14, 2003, and received by CDC from the Vaccine Adverse Event Reporting System (VAERS) as of February 18.

Potentially life-threatening and moderate-to-serious events are classified on the basis of evidence in support of the reported diagnoses. For probable cases, other causes are excluded, and supportive information is available. Events are classified as suspected if they have clinical features compatible with the diagnosis but either further investigation is required or additional investigation of the case did not provide supporting evidence for the diagnosis and did not identify an alternative diagnosis. CDC and state health departments also receive reports of other events that are associated temporally with smallpox vaccination. Reported adverse events are not necessarily associated with vaccination, and some or all of these events might be coincidental.

During January 24-February 14, 2003, smallpox vaccine was administered to 4,213 civilian health-care workers in 27 jurisdictions. No potentially life threatening or moderateto-severe adverse events have been reported. Among seven vaccinees with reported nonserious adverse events, the most common signs and symptoms were fever $(\mathrm{n}=\mathrm{two})$, rash
TABLE. Number of cases* of adverse events after smallpox vaccination among civilians, by type - United States, January 24-February 18, 2003

\begin{tabular}{|c|c|c|}
\hline \multirow[b]{2}{*}{ Adverse events } & \multicolumn{2}{|c|}{ No. cases } \\
\hline & Suspected & Probable \\
\hline \multicolumn{3}{|l|}{ Potentially life-threatening events } \\
\hline Eczema vaccinatum & $-c^{\dagger}$ & - \\
\hline $\begin{array}{l}\text { Erythema multiforme major (Stevens-Johnson } \\
\text { syndrome) }\end{array}$ & - & - \\
\hline Fetal vaccinia & - & - \\
\hline Post-vaccinial encephalitis or encephalomyelitis & - & - \\
\hline Progressive vaccinia & - & - \\
\hline \multicolumn{3}{|l|}{ Moderate-to-severe events } \\
\hline Generalized vaccinia & - & - \\
\hline Inadvertent inoculation, non-ocular & - & - \\
\hline Ocular vaccinia & - & - \\
\hline \multirow[t]{2}{*}{ Pyogenic infection of vaccination site } & - & - \\
\hline & \multicolumn{2}{|c|}{ No. cases } \\
\hline \multicolumn{3}{|l|}{ Other events of concern } \\
\hline Other serious adverse events $\S$ & \multicolumn{2}{|c|}{ - } \\
\hline Other nonserious adverse events" & \multicolumn{2}{|c|}{7} \\
\hline Vaccinia immune globulin release & \multicolumn{2}{|c|}{-} \\
\hline Vaccinia transmission to contacts & \multicolumn{2}{|c|}{-} \\
\hline \multicolumn{3}{|c|}{$\begin{array}{l}\text { * Under investigation or completed as of February } 18,2002 ; \text { numbers and } \\
\text { classifications of adverse events will be updated regularly in MMWR as } \\
\text { more information becomes available. } \\
\text { } \text { No cases reported. } \\
\text { §vents that result in hospitalization, permanent disability, life-threatening } \\
\text { illness, or death; these events are associated temporally with smallpox } \\
\text { vaccination but have not been documented to be associated causally } \\
\text { qith vaccination. } \\
\text { Include expected self-limited responses to smallpox vaccination (e.g., } \\
\text { fatigue, headache, pruritis, local reaction at vaccination site, regional } \\
\text { lymphadenopathy, lymphangitis, fever, myalgia and chills, and nausea); } \\
\text { additional events are associated temporally with smallpox vaccination } \\
\text { but have not been documented to be associated causally with vaccination. }\end{array}$} \\
\hline
\end{tabular}

( $\mathrm{n}=\mathrm{two})$, malaise ( $\mathrm{n}=$ two), pruritus $(\mathrm{n}=$ two), hypertension ( $\mathrm{n}=\mathrm{two})$, and pharyngitis $(\mathrm{n}=\mathrm{two})$.

Surveillance for adverse events during the civilian smallpox vaccination program is ongoing. Regular surveillance reports will be published in $M M W R$.

\section{Reference}

1. CDC. Smallpox Vaccine Adverse Events Monitoring and Response System for the first stage of the smallpox vaccination program. MMWR 2002;52:88-9.

\section{Notice to Readers}

\section{Release of Atlas Highlighting Burden of Stroke Death}

Stroke is the third leading cause of death in the United States and the leading cause of serious, long-term disability. Each year, approximately 700,000 U.S. residents experience a new or recurrent stroke; an estimated 500,000 residents will have their first stroke (1). In 1999, a total of 167,000 deaths from stroke occurred; of these, approximately half occurred out of 
hospital (2). A new CDC report, The Atlas of Stroke Mortality: Racial, Ethnic, and Geographic Disparities in the United States (3) provides, for the first time, an extensive series of national and state maps that show local disparities in stroke death rates for the five largest racial/ethnic groups in the United States. The maps provide health-care professionals and concerned persons with county-level maps of stroke mortality that are essential for tailoring stroke-prevention policies and programs to the needs of communities.

High blood pressure and atrial fibrillation are important risk factors for stroke that can be prevented and controlled in reducing stroke-related deaths and disability. CDC funds health departments in 29 states and the District of Columbia to develop effective strategies for reducing the burden of cardiovascular diseases (e.g., heart disease and stroke) with an emphasis on policy and systems changes. Through these statebased programs, CDC aims to eliminate disparities in treatment, risk factors, and disease; delay the onset of disease; postpone death from cardiovascular disease; and diminish disabling conditions.
Additional information is available at http://www.cdc.gov/ nccdphp/cvd/stateprogram.htm. Detailed maps of stroke and heart disease mortality at state and county levels are available at http://www.cdc.gov/cvh. Additional information about stroke also is available from the National Institute of Neurological Disorders and Stroke at http://www.ninds.nih.gov, the American Stroke Association Division of the American Heart Association at http://www.strokeassociation.org, the Brain Attack Coalition at http://www.stroke-site.org, and the National Stroke Association at http://www.stroke.org.

\section{References}

1. American Heart Association. Heart and Stroke Statistics-2003 Update. Dallas, Texas: American Heart Association, 2003. Available at http://www.americanheart.org/statistics.

2. CDC. State-specific mortality from stroke and distribution of place of death-United States, 1999. MMWR 2002;51:429-33.

3. Casper ML, Barnett E, Williams I, Halverson J, Braham V, Greenlund K. The Atlas of Stroke Mortality: Racial, Ethnic, and Geographic Disparities in the United States, 1st ed. Atlanta, Georgia: U.S. Department of Health and Human Services, CDC, February 2003. 
FIGURE I. Selected notifiable disease reports, United States, comparison of provisional 4-week totals ending February 15, 2003, with historical data

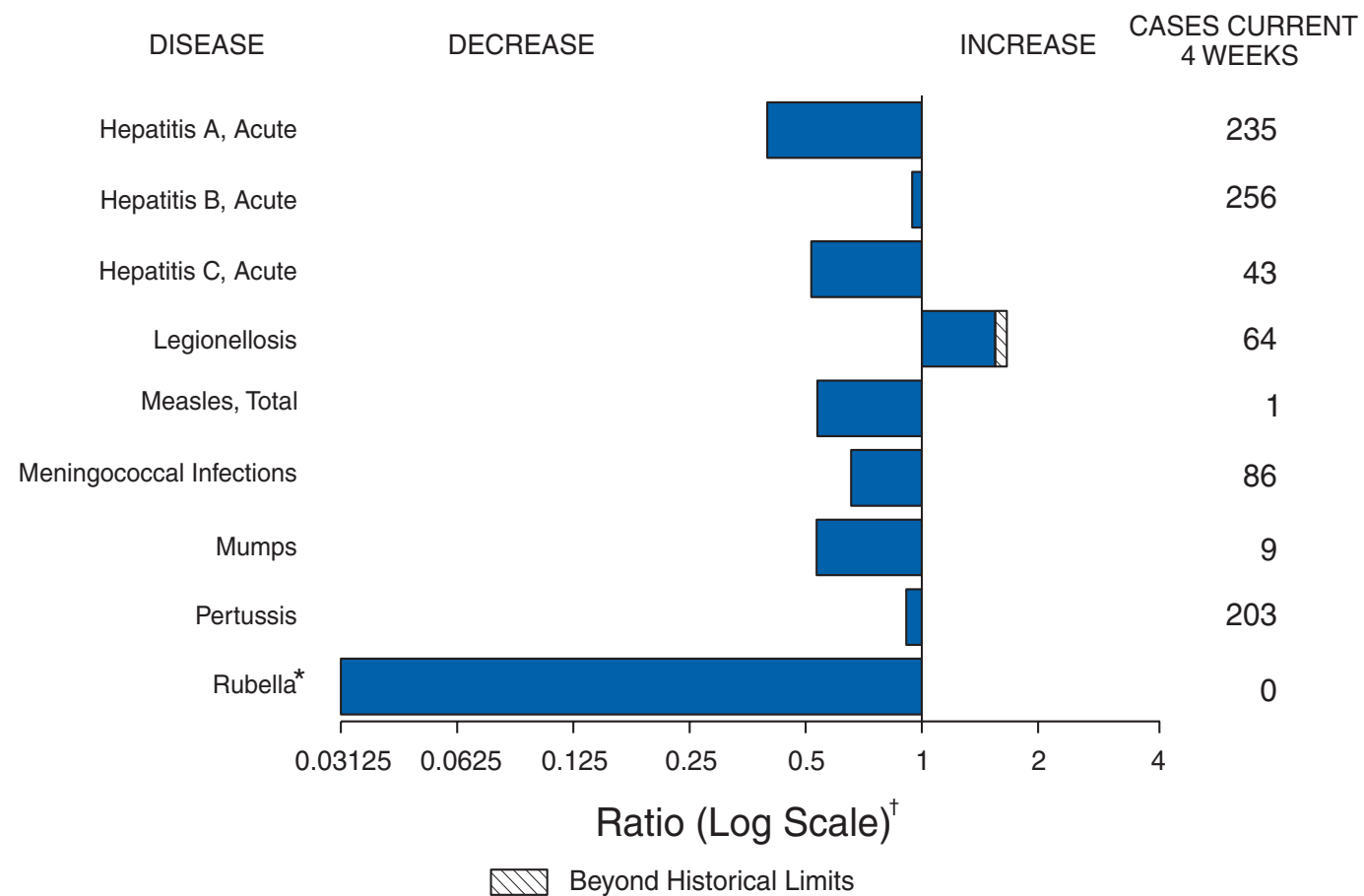

* No rubella cases were reported for the current 4-week period yielding a ratio for week 7 of zero (0).

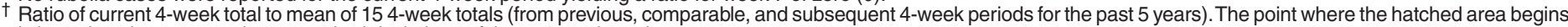
is based on the mean and two standard deviations of these 4-week totals.

TABLE I. Summary of provisional cases of selected notifiable diseases, United States, cumulative, week ending February 15, 2003 (7th Week)

Anthrax

Botulism:

Chancroid

Cholera

Cyclosporiasis $^{\dagger}$

Diphtheria

Ehrlichiosis:

human granulocytic (HGE) ${ }^{\dagger}$ human monocytic (HME) ${ }^{\dagger}$ other and unspecified

Encephalitis/Meningitis:

foodborne

infant

other (wound \& unspecified)

California serogroup viral ${ }^{\dagger}$

eastern equine

Powassan $^{\dagger}$

St. Louis ${ }^{\dagger}$

western equine ${ }^{\dagger}$
Hansen disease (leprosy) ${ }^{\dagger}$

Hantavirus pulmonary syndrome ${ }^{\dagger}$

Hemolytic uremic syndrome, postdiarrheal ${ }^{\dagger}$

HIV infection, pediatric ${ }^{\dagger \S}$

Measles, total"

Mumps

Plague

Poliomyelitis, paralytic

Psittacosis ${ }^{\dagger}$

$Q$ fever $^{\dagger}$

Rabies, human

Rubella

Rubella, congenital

Streptococcal toxic-shock syndrome ${ }^{\dagger}$

Tetanus

Toxic-shock syndrome

Trichinosis

Tularemia $^{\dagger}$

Yellow fever

\begin{tabular}{|c|c|}
\hline $\begin{array}{l}\text { Cum. } \\
2003 \\
\end{array}$ & $\begin{array}{l}\text { Cum. } \\
2002 \\
\end{array}$ \\
\hline 4 & 3 \\
\hline 3 & - \\
\hline 9 & 11 \\
\hline- & 21 \\
\hline 2 & 2 \\
\hline 21 & 26 \\
\hline- & - \\
\hline - & - \\
\hline 3 & 8 \\
\hline 6 & 3 \\
\hline- & - \\
\hline- & 1 \\
\hline- & 1 \\
\hline 11 & 11 \\
\hline 2 & - \\
\hline 5 & 15 \\
\hline 1 & 2 \\
\hline 2 & 3 \\
\hline- & - \\
\hline
\end{tabular}

$-:$ No reported cases.

* Incidence data for reporting years 2002 and 2003 are provisional and cumulative (year-to-date).

Not notifiable in all states.

$\S$ Updated monthly from reports to the Division of HIV/AIDS Prevention — Surveillance and Epidemiology, National Center for HIV, STD, and TB Prevention

(NCHSTP). Last update December 22, 2002.

I Of two cases reported in 2002 and two cases reported in 2003, in each year, one was indigenous and one was imported from another country. 
TABLE II. Provisional cases of selected notifiable diseases, United States, weeks ending February 15, 2003, and February 16, 2002 (7th Week)*

\begin{tabular}{|c|c|c|c|c|c|c|c|c|c|c|}
\hline \multirow[b]{2}{*}{ Reporting area } & \multicolumn{2}{|c|}{ AIDS } & \multicolumn{2}{|c|}{ Chlamydia $^{\dagger}$} & \multicolumn{2}{|c|}{ Coccidiodomycosis } & \multicolumn{2}{|c|}{ Cryptosporidiosis } & \multicolumn{2}{|c|}{$\begin{array}{c}\text { Encephalitis/Meningitis } \\
\text { West Nile }\end{array}$} \\
\hline & $\begin{array}{l}\text { Cum. } \\
2003^{\S}\end{array}$ & $\begin{array}{l}\text { Cum. } \\
2002\end{array}$ & $\begin{array}{l}\text { Cum. } \\
2003\end{array}$ & $\begin{array}{l}\text { Cum. } \\
2002\end{array}$ & $\begin{array}{l}\text { Cum. } \\
2003\end{array}$ & $\begin{array}{l}\text { Cum. } \\
2002\end{array}$ & $\begin{array}{l}\text { Cum. } \\
2003\end{array}$ & $\begin{array}{l}\text { Cum. } \\
2002\end{array}$ & $\begin{array}{l}\text { Cum. } \\
2003\end{array}$ & $\begin{array}{l}\text { Cum. } \\
2002\end{array}$ \\
\hline UNITED STATES & - & 3,410 & 78,829 & 101,312 & 473 & 332 & 135 & 272 & - & - \\
\hline $\begin{array}{l}\text { NEW ENGLAND } \\
\text { Maine } \\
\text { N.H. } \\
\text { Vt. } \\
\text { Mass. } \\
\text { R.I. } \\
\text { Conn. }\end{array}$ & $\begin{array}{l}- \\
- \\
- \\
- \\
- \\
-\end{array}$ & $\begin{array}{r}111 \\
1 \\
2 \\
3 \\
76 \\
5 \\
24\end{array}$ & $\begin{array}{r}2,660 \\
138 \\
182 \\
160 \\
958 \\
350 \\
872\end{array}$ & $\begin{array}{r}3,472 \\
181 \\
224 \\
92 \\
1,319 \\
358 \\
1,298\end{array}$ & $\begin{array}{l}\text { N } \\
- \\
- \\
- \\
- \\
-\end{array}$ & $\begin{array}{l}- \\
\text { N } \\
- \\
- \\
- \\
- \\
-\end{array}$ & $\begin{array}{r}10 \\
1 \\
- \\
1 \\
5 \\
1 \\
2\end{array}$ & $\begin{array}{l}7 \\
- \\
2 \\
- \\
2 \\
3 \\
-\end{array}$ & $\begin{array}{l}- \\
- \\
- \\
- \\
-\end{array}$ & $\begin{array}{l}- \\
- \\
- \\
- \\
- \\
-\end{array}$ \\
\hline $\begin{array}{l}\text { MID. ATLANTIC } \\
\text { Upstate N.Y. } \\
\text { N.Y. City } \\
\text { N.J. } \\
\text { Pa. }\end{array}$ & $\begin{array}{l}- \\
- \\
- \\
-\end{array}$ & $\begin{array}{r}835 \\
46 \\
587 \\
145 \\
57\end{array}$ & $\begin{array}{r}5,340 \\
1,495 \\
645 \\
1,187 \\
2,013\end{array}$ & $\begin{array}{r}10,831 \\
1,079 \\
3,913 \\
1,835 \\
4,004\end{array}$ & $\begin{array}{l}- \\
- \\
- \\
-\end{array}$ & $\begin{array}{l}- \\
- \\
- \\
\text { N }\end{array}$ & $\begin{array}{r}30 \\
4 \\
24 \\
1 \\
1\end{array}$ & $\begin{array}{r}22 \\
3 \\
13 \\
1 \\
5\end{array}$ & $\begin{array}{l}- \\
- \\
- \\
-\end{array}$ & $\begin{array}{l}- \\
- \\
- \\
-\end{array}$ \\
\hline $\begin{array}{l}\text { E.N. CENTRAL } \\
\text { Ohio } \\
\text { Ind. } \\
\text { III. } \\
\text { Mich. } \\
\text { Wis. }\end{array}$ & $\begin{array}{l}- \\
- \\
- \\
- \\
-\end{array}$ & $\begin{array}{r}370 \\
103 \\
52 \\
176 \\
31 \\
8\end{array}$ & $\begin{array}{r}14,820 \\
5,665 \\
1,763 \\
2,502 \\
3,520 \\
1,370\end{array}$ & $\begin{array}{r}18,556 \\
4,822 \\
2,156 \\
5,398 \\
3,880 \\
2,300\end{array}$ & $\begin{array}{l}1 \\
- \\
\mathrm{N} \\
- \\
1 \\
-\end{array}$ & $\begin{array}{r}2 \\
- \\
\mathrm{N} \\
- \\
2 \\
-\end{array}$ & $\begin{array}{r}21 \\
7 \\
2 \\
2 \\
9 \\
1\end{array}$ & $\begin{array}{r}88 \\
18 \\
8 \\
8 \\
18 \\
14 \\
30\end{array}$ & $\begin{array}{l}- \\
- \\
- \\
- \\
- \\
-\end{array}$ & $\begin{array}{l}- \\
- \\
- \\
- \\
-\end{array}$ \\
\hline $\begin{array}{l}\text { W.N. CENTRAL } \\
\text { Minn. } \\
\text { lowa } \\
\text { Mo. } \\
\text { N. Dak. } \\
\text { S. Dak. } \\
\text { Nebr. } \\
\text { Kans. }\end{array}$ & $\begin{array}{l}- \\
- \\
- \\
- \\
- \\
-\end{array}$ & $\begin{array}{r}48 \\
9 \\
15 \\
22 \\
- \\
- \\
- \\
2\end{array}$ & $\begin{array}{r}4,220 \\
911 \\
174 \\
1,500 \\
41 \\
340 \\
293 \\
961\end{array}$ & $\begin{array}{r}5,483 \\
1,446 \\
408 \\
1,876 \\
143 \\
285 \\
399 \\
926\end{array}$ & $\begin{array}{r}- \\
- \\
\mathrm{N} \\
- \\
\mathrm{N} \\
- \\
- \\
\mathrm{N}\end{array}$ & $\begin{array}{r}- \\
- \\
\mathrm{N} \\
- \\
\mathrm{N} \\
- \\
\mathrm{N}\end{array}$ & $\begin{array}{r}14 \\
6 \\
3 \\
2 \\
- \\
3 \\
- \\
-\end{array}$ & $\begin{array}{r}19 \\
8 \\
2 \\
4 \\
- \\
- \\
3 \\
2\end{array}$ & $\begin{array}{l}- \\
- \\
- \\
- \\
- \\
-\end{array}$ & $\begin{array}{l}- \\
- \\
- \\
- \\
- \\
- \\
-\end{array}$ \\
\hline $\begin{array}{l}\text { S. ATLANTIC } \\
\text { Del. } \\
\text { Md. } \\
\text { D.C. } \\
\text { Va. } \\
\text { W. Va. } \\
\text { N.C. } \\
\text { S.C. } \\
\text { Ga. } \\
\text { Fla. }\end{array}$ & $\begin{array}{l}- \\
- \\
- \\
- \\
- \\
- \\
- \\
- \\
-\end{array}$ & $\begin{array}{r}1,093 \\
21 \\
140 \\
19 \\
107 \\
6 \\
45 \\
102 \\
375 \\
278\end{array}$ & $\begin{array}{r}17,993 \\
422 \\
2,012 \\
394 \\
1,824 \\
299 \\
3,507 \\
1,414 \\
3,400 \\
4,721\end{array}$ & $\begin{array}{r}18,007 \\
345 \\
1,924 \\
460 \\
1,958 \\
321 \\
2,558 \\
1,852 \\
3,386 \\
5,203\end{array}$ & $\begin{array}{l}- \\
\mathrm{N} \\
- \\
- \\
- \\
\mathrm{N} \\
- \\
- \\
- \\
\mathrm{N}\end{array}$ & $\begin{array}{l}- \\
\mathrm{N} \\
- \\
- \\
- \\
\mathrm{N} \\
- \\
- \\
-\end{array}$ & $\begin{array}{r}26 \\
1 \\
5 \\
- \\
- \\
- \\
3 \\
1 \\
12 \\
4\end{array}$ & $\begin{array}{r}56 \\
- \\
- \\
1 \\
- \\
- \\
7 \\
- \\
39 \\
9\end{array}$ & $\begin{array}{l}- \\
- \\
- \\
- \\
- \\
- \\
- \\
-\end{array}$ & $\begin{array}{l}- \\
- \\
- \\
- \\
- \\
- \\
- \\
- \\
- \\
-\end{array}$ \\
\hline $\begin{array}{l}\text { E.S. CENTRAL } \\
\text { Ky. } \\
\text { Tenn. } \\
\text { Ala. } \\
\text { Miss. }\end{array}$ & $\begin{array}{l}- \\
- \\
- \\
-\end{array}$ & $\begin{array}{r}136 \\
16 \\
66 \\
20 \\
34\end{array}$ & $\begin{array}{r}6,198 \\
857 \\
2,046 \\
1,736 \\
1,559\end{array}$ & $\begin{array}{l}6,877 \\
1,143 \\
2,241 \\
2,255 \\
1,238\end{array}$ & $\begin{array}{l}- \\
- \\
- \\
-\end{array}$ & $\begin{array}{l}- \\
- \\
- \\
\text { N }\end{array}$ & $\begin{array}{r}11 \\
- \\
5 \\
5 \\
1\end{array}$ & $\begin{array}{r}11 \\
1 \\
1 \\
8 \\
1\end{array}$ & $\begin{array}{l}- \\
- \\
- \\
-\end{array}$ & $\begin{array}{l}- \\
- \\
- \\
-\end{array}$ \\
\hline $\begin{array}{l}\text { W.S. CENTRAL } \\
\text { Ark. } \\
\text { La. } \\
\text { Okla. } \\
\text { Tex. }\end{array}$ & $\begin{array}{l}- \\
- \\
- \\
-\end{array}$ & $\begin{array}{r}379 \\
15 \\
65 \\
7 \\
292\end{array}$ & $\begin{array}{r}12,070 \\
657 \\
2,067 \\
894 \\
8,452\end{array}$ & $\begin{array}{r}14,167 \\
852 \\
2,329 \\
1,162 \\
9,824\end{array}$ & $\begin{array}{l}- \\
- \\
N \\
-\end{array}$ & $\begin{array}{l}- \\
- \\
N \\
-\end{array}$ & $\begin{array}{l}2 \\
1 \\
- \\
1 \\
-\end{array}$ & $\begin{array}{l}8 \\
2 \\
1 \\
1 \\
4\end{array}$ & $\begin{array}{l}- \\
- \\
- \\
-\end{array}$ & $\begin{array}{l}- \\
- \\
- \\
-\end{array}$ \\
\hline $\begin{array}{l}\text { MOUNTAIN } \\
\text { Mont. } \\
\text { Idaho } \\
\text { Wyo. } \\
\text { Colo. } \\
\text { N. Mex. } \\
\text { Ariz. } \\
\text { Utah } \\
\text { Nev. }\end{array}$ & $\begin{array}{l}- \\
- \\
- \\
- \\
- \\
- \\
- \\
- \\
-\end{array}$ & $\begin{array}{r}106 \\
3 \\
1 \\
1 \\
20 \\
6 \\
39 \\
7 \\
29\end{array}$ & $\begin{array}{r}4,287 \\
238 \\
355 \\
157 \\
1,100 \\
43 \\
1,878 \\
196 \\
320\end{array}$ & $\begin{array}{r}6,308 \\
362 \\
235 \\
98 \\
1,854 \\
1,065 \\
1,852 \\
51 \\
791\end{array}$ & $\begin{array}{r}406 \\
- \\
- \\
- \\
\mathrm{N} \\
- \\
404 \\
1 \\
1\end{array}$ & $\begin{array}{r}236 \\
- \\
- \\
- \\
\mathrm{N} \\
1 \\
229 \\
2 \\
4\end{array}$ & $\begin{array}{r}10 \\
- \\
5 \\
- \\
2 \\
- \\
2 \\
1 \\
-\end{array}$ & $\begin{array}{l}8 \\
- \\
2 \\
- \\
2 \\
- \\
1 \\
2 \\
1\end{array}$ & $\begin{array}{l}- \\
- \\
- \\
- \\
- \\
- \\
- \\
-\end{array}$ & $\begin{array}{l}- \\
- \\
- \\
- \\
- \\
- \\
- \\
- \\
-\end{array}$ \\
\hline $\begin{array}{l}\text { PACIFIC } \\
\text { Wash. } \\
\text { Oreg. } \\
\text { Calif. } \\
\text { Alaska } \\
\text { Hawaii }\end{array}$ & $\begin{array}{l}- \\
- \\
- \\
- \\
-\end{array}$ & $\begin{array}{r}332 \\
39 \\
75 \\
215 \\
- \\
3\end{array}$ & $\begin{array}{r}11,241 \\
2,018 \\
776 \\
7,426 \\
458 \\
563\end{array}$ & $\begin{array}{r}17,611 \\
1,846 \\
772 \\
14,025 \\
431 \\
537\end{array}$ & $\begin{array}{r}66 \\
N \\
- \\
66 \\
- \\
-\end{array}$ & $\begin{array}{r}94 \\
\mathrm{~N} \\
- \\
94 \\
- \\
-\end{array}$ & $\begin{array}{r}11 \\
- \\
3 \\
8 \\
- \\
-\end{array}$ & $\begin{array}{r}53 \\
10 \\
7 \\
36 \\
- \\
-\end{array}$ & $\begin{array}{l}- \\
- \\
- \\
- \\
-\end{array}$ & $\begin{array}{l}- \\
- \\
- \\
- \\
-\end{array}$ \\
\hline $\begin{array}{l}\text { Guam } \\
\text { P.R. } \\
\text { V.I. } \\
\text { Amer. Samoa } \\
\text { C.N.M.I. }\end{array}$ & $\begin{array}{l}- \\
- \\
\\
\end{array}$ & $\begin{array}{r}- \\
68 \\
33 \\
\cup\end{array}$ & $\begin{array}{r}104 \\
\bar{U} \\
-\end{array}$ & $\begin{array}{r}- \\
253 \\
28 \\
U \\
U\end{array}$ & $\begin{array}{c}\bar{N} \\
\bar{U} \\
\overline{-}\end{array}$ & $\begin{array}{c}\bar{N} \\
\bar{U} \\
U\end{array}$ & $\begin{array}{l}- \\
- \\
\text { U } \\
-\end{array}$ & $\begin{array}{l}- \\
- \\
U \\
U\end{array}$ & $\begin{array}{l}- \\
- \\
\text { U }\end{array}$ & $\begin{array}{l}- \\
- \\
U \\
U\end{array}$ \\
\hline
\end{tabular}

$\mathrm{N}$ : Not notifiable. $\quad \mathrm{U}$ : Unavailable. $\quad-:$ No reported cases.

C.N.M.I.: Commonwealth of Northern Mariana Islands.

* Incidence data for reporting years 2002 and 2003 are provisional and cumulative (year-to-date).

+ Chlamydia refers to genital infections caused by $C$. trachomatis.

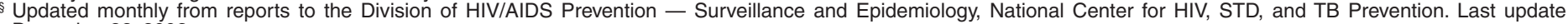
December 22, 2002. 
TABLE II. (Continued) Provisional cases of selected notifiable diseases, United States, weeks ending February 15, 2003, and February 16, 2002 (7th Week)*

\begin{tabular}{|c|c|c|c|c|c|c|c|c|c|c|}
\hline \multirow[b]{3}{*}{ Reporting area } & \multicolumn{6}{|c|}{ Escherichia coli, Enterohemorrhagic (EHEC) } & \multirow{2}{*}{\multicolumn{2}{|c|}{ Giardiasis }} & \multirow{2}{*}{\multicolumn{2}{|c|}{ Gonorrhea }} \\
\hline & \multicolumn{2}{|c|}{ 0157:H7 } & \multicolumn{2}{|c|}{$\begin{array}{l}\text { Shiga toxin positive, } \\
\text { serogroup non-0157 }\end{array}$} & \multicolumn{2}{|c|}{$\begin{array}{c}\text { Shiga toxin positive, } \\
\text { not serogrouped }\end{array}$} & & & & \\
\hline & $\begin{array}{l}\text { Cum. } \\
2003 \\
\end{array}$ & $\begin{array}{l}\text { Cum. } \\
2002 \\
\end{array}$ & $\begin{array}{l}\text { Cum. } \\
2003\end{array}$ & $\begin{array}{l}\text { Cum. } \\
2002 \\
\end{array}$ & $\begin{array}{l}\text { Cum. } \\
2003 \\
\end{array}$ & $\begin{array}{l}\text { Cum. } \\
2002\end{array}$ & $\begin{array}{l}\text { Cum. } \\
2003 \\
\end{array}$ & $\begin{array}{l}\text { Cum. } \\
2002 \\
\end{array}$ & $\begin{array}{l}\text { Cum. } \\
2003 \\
\end{array}$ & $\begin{array}{l}\text { Cum } \\
2002 \\
\end{array}$ \\
\hline UNITED STATES & 99 & 165 & 7 & 8 & 7 & 1 & 1,758 & 1,772 & 34,028 & 45,885 \\
\hline $\begin{array}{l}\text { NEW ENGLAND } \\
\text { Maine } \\
\text { N.H. } \\
\text { Vt. } \\
\text { Mass. } \\
\text { R.I. } \\
\text { Conn. }\end{array}$ & $\begin{array}{l}9 \\
- \\
2 \\
\overline{3} \\
- \\
4\end{array}$ & $\begin{array}{l}7 \\
- \\
1 \\
1 \\
2 \\
3\end{array}$ & $\begin{array}{l}- \\
- \\
- \\
- \\
- \\
-\end{array}$ & $\begin{array}{l}1 \\
- \\
- \\
- \\
1 \\
- \\
-\end{array}$ & $\begin{array}{l}- \\
- \\
- \\
- \\
- \\
-\end{array}$ & $\begin{array}{l}- \\
- \\
- \\
- \\
-\end{array}$ & $\begin{array}{r}64 \\
10 \\
5 \\
9 \\
36 \\
4 \\
-\end{array}$ & $\begin{array}{r}206 \\
23 \\
9 \\
18 \\
108 \\
18 \\
30\end{array}$ & $\begin{array}{r}730 \\
5 \\
15 \\
14 \\
269 \\
131 \\
296\end{array}$ & $\begin{array}{r}1,109 \\
13 \\
12 \\
14 \\
491 \\
118 \\
461\end{array}$ \\
\hline $\begin{array}{l}\text { MID. ATLANTIC } \\
\text { Upstate N.Y. } \\
\text { N.Y. City } \\
\text { N.J. } \\
\text { Pa. }\end{array}$ & $\begin{array}{l}7 \\
4 \\
1 \\
2 \\
\mathrm{~N}\end{array}$ & $\begin{array}{l}9 \\
5 \\
- \\
4 \\
\mathrm{~N}\end{array}$ & $\begin{array}{l}- \\
- \\
- \\
-\end{array}$ & $\begin{array}{l}- \\
- \\
- \\
-\end{array}$ & $\begin{array}{l}2 \\
2 \\
- \\
- \\
-\end{array}$ & $\begin{array}{l}- \\
- \\
- \\
-\end{array}$ & $\begin{array}{r}548 \\
65 \\
465 \\
11 \\
7\end{array}$ & $\begin{array}{r}335 \\
61 \\
125 \\
64 \\
85\end{array}$ & $\begin{array}{r}2,318 \\
708 \\
218 \\
685 \\
707\end{array}$ & $\begin{array}{r}5,096 \\
590 \\
1,697 \\
1,073 \\
1,736\end{array}$ \\
\hline $\begin{array}{l}\text { E.N. CENTRAL } \\
\text { Ohio } \\
\text { Ind. } \\
\text { IIl. } \\
\text { Mich. } \\
\text { Wis. }\end{array}$ & $\begin{array}{r}25 \\
7 \\
2 \\
5 \\
7 \\
4\end{array}$ & $\begin{array}{r}58 \\
12 \\
4 \\
20 \\
9 \\
13\end{array}$ & $\begin{array}{l}- \\
- \\
- \\
- \\
-\end{array}$ & $\begin{array}{l}- \\
- \\
- \\
- \\
-\end{array}$ & $\begin{array}{l}2 \\
2 \\
- \\
- \\
- \\
-\end{array}$ & $\begin{array}{l}- \\
- \\
- \\
- \\
-\end{array}$ & $\begin{array}{r}238 \\
122 \\
- \\
27 \\
84 \\
5\end{array}$ & $\begin{array}{r}419 \\
116 \\
- \\
124 \\
109 \\
70\end{array}$ & $\begin{array}{r}7,888 \\
3,630 \\
691 \\
1,228 \\
1,865 \\
474\end{array}$ & $\begin{array}{r}9,565 \\
2,706 \\
989 \\
3,010 \\
2,078 \\
782\end{array}$ \\
\hline $\begin{array}{l}\text { W.N. CENTRAL } \\
\text { Minn. } \\
\text { lowa } \\
\text { Mo. } \\
\text { N. Dak. } \\
\text { S. Dak. } \\
\text { Nebr. } \\
\text { Kans. }\end{array}$ & $\begin{array}{r}16 \\
8 \\
1 \\
3 \\
- \\
1 \\
3 \\
-\end{array}$ & $\begin{array}{r}25 \\
8 \\
7 \\
3 \\
- \\
- \\
4 \\
3\end{array}$ & $\begin{array}{l}2 \\
2 \\
- \\
\mathrm{N} \\
- \\
- \\
- \\
-\end{array}$ & $\begin{array}{c}3 \\
3 \\
- \\
N \\
- \\
- \\
- \\
-\end{array}$ & $\begin{array}{l}2 \\
- \\
- \\
N \\
1 \\
- \\
- \\
1\end{array}$ & $\begin{array}{c}- \\
- \\
\bar{N} \\
- \\
- \\
-\end{array}$ & $\begin{array}{r}160 \\
43 \\
32 \\
27 \\
4 \\
7 \\
27 \\
20\end{array}$ & $\begin{array}{r}153 \\
36 \\
35 \\
41 \\
- \\
8 \\
15 \\
18\end{array}$ & $\begin{array}{r}1,691 \\
294 \\
31 \\
912 \\
2 \\
17 \\
69 \\
366\end{array}$ & $\begin{array}{r}2,417 \\
444 \\
110 \\
1,194 \\
5 \\
36 \\
172 \\
456\end{array}$ \\
\hline $\begin{array}{l}\text { S. ATLANTIC } \\
\text { Del. } \\
\text { Md. } \\
\text { D.C. } \\
\text { Va. } \\
\text { W.Va. } \\
\text { N.C. } \\
\text { S.C. } \\
\text { Ga. } \\
\text { Fla. }\end{array}$ & $\begin{array}{r}12 \\
- \\
- \\
- \\
1 \\
- \\
3 \\
- \\
3 \\
5\end{array}$ & $\begin{array}{r}25 \\
1 \\
- \\
- \\
2 \\
- \\
4 \\
- \\
17 \\
1\end{array}$ & $\begin{array}{l}1 \\
- \\
- \\
- \\
- \\
- \\
- \\
- \\
-\end{array}$ & $\begin{array}{l}2 \\
- \\
- \\
- \\
- \\
- \\
- \\
- \\
1 \\
1\end{array}$ & $\begin{array}{l}- \\
- \\
- \\
- \\
- \\
- \\
- \\
-\end{array}$ & $\begin{array}{l}- \\
- \\
- \\
- \\
- \\
- \\
-\end{array}$ & $\begin{array}{r}293 \\
6 \\
16 \\
- \\
16 \\
- \\
- \\
4 \\
143 \\
108\end{array}$ & $\begin{array}{r}349 \\
10 \\
17 \\
8 \\
9 \\
2 \\
- \\
1 \\
103 \\
199\end{array}$ & $\begin{array}{r}9,729 \\
201 \\
1,029 \\
331 \\
1,080 \\
96 \\
2,045 \\
853 \\
1,828 \\
2,266\end{array}$ & $\begin{array}{r}11,209 \\
237 \\
1,129 \\
398 \\
1,252 \\
129 \\
2,087 \\
1,049 \\
2,034 \\
2,894\end{array}$ \\
\hline $\begin{array}{l}\text { E.S. CENTRAL } \\
\text { Ky. } \\
\text { Tenn. } \\
\text { Ala. } \\
\text { Miss. }\end{array}$ & $\begin{array}{l}5 \\
- \\
3 \\
2 \\
-\end{array}$ & $\begin{array}{l}1 \\
- \\
1 \\
-\end{array}$ & $\begin{array}{l}- \\
- \\
- \\
- \\
-\end{array}$ & $\begin{array}{l}- \\
- \\
- \\
- \\
-\end{array}$ & $\begin{array}{l}- \\
- \\
- \\
-\end{array}$ & $\begin{array}{l}- \\
- \\
- \\
-\end{array}$ & $\begin{array}{r}38 \\
- \\
14 \\
24 \\
-\end{array}$ & $\begin{array}{r}34 \\
11 \\
23 \\
-\end{array}$ & $\begin{array}{r}3,271 \\
403 \\
956 \\
1,121 \\
791\end{array}$ & $\begin{array}{r}4,208 \\
469 \\
1,386 \\
1,556 \\
797\end{array}$ \\
\hline $\begin{array}{l}\text { W.S. CENTRAL } \\
\text { Ark. } \\
\text { La. } \\
\text { Okla. } \\
\text { Tex. }\end{array}$ & $\begin{array}{l}1 \\
1 \\
- \\
- \\
-\end{array}$ & $\begin{array}{l}3 \\
- \\
- \\
- \\
3\end{array}$ & $\begin{array}{l}- \\
- \\
- \\
-\end{array}$ & $\begin{array}{l}- \\
- \\
- \\
-\end{array}$ & $\begin{array}{l}- \\
- \\
- \\
-\end{array}$ & $\begin{array}{l}1 \\
- \\
- \\
- \\
1\end{array}$ & $\begin{array}{r}23 \\
15 \\
- \\
8 \\
-\end{array}$ & $\begin{array}{r}11 \\
11 \\
- \\
- \\
-\end{array}$ & $\begin{array}{r}5,248 \\
441 \\
1,325 \\
376 \\
3,106\end{array}$ & $\begin{array}{r}6,638 \\
611 \\
1,573 \\
484 \\
3,970\end{array}$ \\
\hline $\begin{array}{l}\text { MOUNTAIN } \\
\text { Mont. } \\
\text { Idaho } \\
\text { Wyo. } \\
\text { Colo. } \\
\text { N. Mex. } \\
\text { Ariz. } \\
\text { Utah } \\
\text { Nev. }\end{array}$ & $\begin{array}{r}12 \\
- \\
2 \\
- \\
3 \\
- \\
4 \\
3 \\
-\end{array}$ & $\begin{array}{r}12 \\
1 \\
1 \\
- \\
2 \\
2 \\
1 \\
3 \\
2\end{array}$ & $\begin{array}{l}3 \\
- \\
2 \\
- \\
- \\
1 \\
- \\
- \\
-\end{array}$ & $\begin{array}{l}1 \\
- \\
- \\
1 \\
- \\
- \\
- \\
- \\
-\end{array}$ & $\begin{array}{l}1 \\
- \\
- \\
- \\
- \\
- \\
-\end{array}$ & $\begin{array}{l}- \\
- \\
- \\
- \\
- \\
-\end{array}$ & $\begin{array}{r}161 \\
2 \\
20 \\
3 \\
47 \\
3 \\
43 \\
31 \\
12\end{array}$ & $\begin{array}{r}137 \\
5 \\
3 \\
1 \\
56 \\
13 \\
12 \\
25 \\
22\end{array}$ & $\begin{array}{r}989 \\
18 \\
12 \\
9 \\
298 \\
23 \\
502 \\
18 \\
109\end{array}$ & $\begin{array}{r}1,523 \\
24 \\
12 \\
8 \\
541 \\
190 \\
507 \\
2 \\
239\end{array}$ \\
\hline $\begin{array}{l}\text { PACIFIC } \\
\text { Wash. } \\
\text { Oreg. } \\
\text { Calif. } \\
\text { Alaska } \\
\text { Hawaii }\end{array}$ & $\begin{array}{r}12 \\
4 \\
1 \\
5 \\
- \\
2\end{array}$ & $\begin{array}{r}25 \\
4 \\
7 \\
14 \\
- \\
-\end{array}$ & $\begin{array}{l}1 \\
- \\
1 \\
- \\
- \\
-\end{array}$ & $\begin{array}{l}1 \\
- \\
1 \\
- \\
- \\
-\end{array}$ & $\begin{array}{l}- \\
- \\
- \\
- \\
-\end{array}$ & $\begin{array}{l}- \\
- \\
- \\
- \\
-\end{array}$ & $\begin{array}{r}233 \\
18 \\
44 \\
148 \\
10 \\
13\end{array}$ & $\begin{array}{r}128 \\
23 \\
77 \\
12 \\
16\end{array}$ & $\begin{array}{r}2,164 \\
361 \\
119 \\
1,491 \\
72 \\
121\end{array}$ & $\begin{array}{r}4,120 \\
408 \\
121 \\
3,425 \\
95 \\
71\end{array}$ \\
\hline $\begin{array}{l}\text { Guam } \\
\text { P.R. } \\
\text { V.I. } \\
\text { Amer. Samoa } \\
\text { C.N.M.I. }\end{array}$ & $\begin{array}{l}\mathrm{N} \\
- \\
\bar{U} \\
-\end{array}$ & $\begin{array}{l}\mathrm{N} \\
- \\
\bar{U} \\
\mathrm{U}\end{array}$ & $\begin{array}{l}- \\
- \\
\\
\end{array}$ & $\begin{array}{l}- \\
- \\
\\
U\end{array}$ & $\begin{array}{l}- \\
- \\
\\
-\end{array}$ & $\begin{array}{l}- \\
- \\
\\
U\end{array}$ & $\begin{array}{l}- \\
- \\
\end{array}$ & $\begin{array}{l}- \\
\bar{U} \\
U\end{array}$ & $\begin{array}{r}11 \\
\\
-\end{array}$ & $\begin{array}{r}81 \\
12 \\
U \\
U\end{array}$ \\
\hline
\end{tabular}

$\mathrm{N}$ : Not notifiable. 
TABLE II. (Continued) Provisional cases of selected notifiable diseases, United States, weeks ending February 15, 2003, and February 16, 2002 (7th Week)*

\begin{tabular}{|c|c|c|c|c|c|c|c|c|c|c|}
\hline \multirow[b]{4}{*}{ Reporting area } & \multicolumn{8}{|c|}{ Haemophilus influenzae, invasive } & \multirow{3}{*}{\multicolumn{2}{|c|}{$\begin{array}{c}\begin{array}{c}\text { Hepatitis } \\
\text { (viral, acute), by type }\end{array} \\
\text { A }\end{array}$}} \\
\hline & \multirow{2}{*}{\multicolumn{2}{|c|}{$\begin{array}{c}\text { All ages } \\
\text { All serotypes }\end{array}$}} & \multicolumn{6}{|c|}{ Age $<5$ years } & & \\
\hline & & & \multicolumn{2}{|c|}{ Serotype B } & \multicolumn{2}{|c|}{ Non-serotype B } & \multicolumn{2}{|c|}{ Unknown serotype } & & \\
\hline & $\begin{array}{l}\text { Cum. } \\
2003 \\
\end{array}$ & $\begin{array}{l}\text { Cum. } \\
2002 \\
\end{array}$ & $\begin{array}{l}\text { Cum. } \\
2003 \\
\end{array}$ & $\begin{array}{l}\text { Cum. } \\
2002 \\
\end{array}$ & $\begin{array}{l}\text { Cum. } \\
2003 \\
\end{array}$ & $\begin{array}{l}\text { Cum. } \\
2002 \\
\end{array}$ & $\begin{array}{l}\text { Cum. } \\
2003 \\
\end{array}$ & $\begin{array}{l}\text { Cum. } \\
2002 \\
\end{array}$ & $\begin{array}{l}\text { Cum. } \\
2003\end{array}$ & $\begin{array}{l}\text { Cum. } \\
2002 \\
\end{array}$ \\
\hline UNITED STATES & 145 & 221 & 2 & - & 19 & 41 & 2 & 2 & 537 & 1,213 \\
\hline $\begin{array}{l}\text { NEW ENGLAND } \\
\text { Maine } \\
\text { N.H. } \\
\text { Vt. } \\
\text { Mass. } \\
\text { R.I. } \\
\text { Conn. }\end{array}$ & $\begin{array}{r}14 \\
- \\
3 \\
4 \\
5 \\
- \\
2\end{array}$ & $\begin{array}{r}19 \\
1 \\
- \\
- \\
12 \\
- \\
6\end{array}$ & $\begin{array}{l}- \\
- \\
- \\
- \\
- \\
-\end{array}$ & $\begin{array}{l}- \\
- \\
- \\
- \\
- \\
-\end{array}$ & $\begin{array}{l}- \\
- \\
- \\
- \\
-\end{array}$ & $\begin{array}{l}5 \\
- \\
- \\
- \\
3 \\
- \\
2\end{array}$ & $\begin{array}{l}- \\
- \\
- \\
- \\
- \\
-\end{array}$ & $\begin{array}{l}- \\
- \\
- \\
- \\
- \\
-\end{array}$ & $\begin{array}{r}15 \\
1 \\
- \\
1 \\
11 \\
- \\
2\end{array}$ & $\begin{array}{r}60 \\
1 \\
3 \\
- \\
32 \\
4 \\
20\end{array}$ \\
\hline $\begin{array}{l}\text { MID. ATLANTIC } \\
\text { Upstate N.Y. } \\
\text { N.Y. City } \\
\text { N.J. } \\
\text { Pa. }\end{array}$ & $\begin{array}{r}10 \\
4 \\
5 \\
1 \\
-\end{array}$ & $\begin{array}{r}38 \\
16 \\
11 \\
8 \\
3\end{array}$ & $\begin{array}{l}- \\
- \\
- \\
-\end{array}$ & $\begin{array}{l}- \\
- \\
- \\
-\end{array}$ & $\begin{array}{l}3 \\
1 \\
2 \\
- \\
-\end{array}$ & $\begin{array}{l}3 \\
2 \\
1 \\
- \\
-\end{array}$ & $\begin{array}{l}- \\
- \\
- \\
-\end{array}$ & $\begin{array}{l}- \\
- \\
- \\
-\end{array}$ & $\begin{array}{r}81 \\
7 \\
74 \\
- \\
-\end{array}$ & $\begin{array}{r}112 \\
13 \\
27 \\
30 \\
42\end{array}$ \\
\hline $\begin{array}{l}\text { E.N. CENTRAL } \\
\text { Ohio } \\
\text { Ind. } \\
\text { III. } \\
\text { Mich. } \\
\text { Wis. }\end{array}$ & $\begin{array}{r}12 \\
6 \\
2 \\
- \\
4 \\
-\end{array}$ & $\begin{array}{r}40 \\
21 \\
3 \\
15 \\
1 \\
-\end{array}$ & $\begin{array}{l}1 \\
- \\
- \\
- \\
1 \\
-\end{array}$ & $\begin{array}{l}- \\
- \\
- \\
- \\
-\end{array}$ & $\begin{array}{l}3 \\
2 \\
1 \\
- \\
- \\
-\end{array}$ & $\begin{array}{l}6 \\
3 \\
1 \\
2 \\
- \\
-\end{array}$ & $\begin{array}{l}- \\
- \\
- \\
- \\
-\end{array}$ & $\begin{array}{l}- \\
- \\
- \\
- \\
-\end{array}$ & $\begin{array}{r}63 \\
22 \\
3 \\
10 \\
25 \\
3\end{array}$ & $\begin{array}{r}140 \\
28 \\
2 \\
65 \\
29 \\
16\end{array}$ \\
\hline $\begin{array}{l}\text { W.N. CENTRAL } \\
\text { Minn. } \\
\text { lowa } \\
\text { Mo. } \\
\text { N. Dak. } \\
\text { S. Dak. } \\
\text { Nebr. } \\
\text { Kans. }\end{array}$ & $\begin{array}{r}14 \\
4 \\
- \\
6 \\
- \\
1 \\
- \\
3\end{array}$ & $\begin{array}{l}3 \\
- \\
1 \\
2 \\
- \\
- \\
-\end{array}$ & $\begin{array}{l}- \\
- \\
- \\
- \\
- \\
-\end{array}$ & $\begin{array}{l}- \\
- \\
- \\
- \\
- \\
-\end{array}$ & $\begin{array}{l}1 \\
- \\
- \\
- \\
- \\
- \\
-\end{array}$ & $\begin{array}{l}- \\
- \\
- \\
- \\
- \\
-\end{array}$ & $\begin{array}{l}2 \\
- \\
- \\
2 \\
- \\
- \\
-\end{array}$ & $\begin{array}{l}1 \\
- \\
- \\
1 \\
- \\
- \\
-\end{array}$ & $\begin{array}{r}20 \\
1 \\
8 \\
3 \\
1 \\
- \\
2 \\
5\end{array}$ & $\begin{array}{r}50 \\
1 \\
12 \\
10 \\
- \\
2 \\
3 \\
22\end{array}$ \\
\hline $\begin{array}{l}\text { S. ATLANTIC } \\
\text { Del. } \\
\text { Md. } \\
\text { D.C. } \\
\text { Va. } \\
\text { W. Va. } \\
\text { N.C. } \\
\text { S.C. } \\
\text { Ga. } \\
\text { Fla. }\end{array}$ & $\begin{array}{r}37 \\
10 \\
- \\
1 \\
- \\
3 \\
1 \\
7 \\
15\end{array}$ & $\begin{array}{r}54 \\
- \\
16 \\
- \\
3 \\
- \\
5 \\
- \\
19 \\
11\end{array}$ & $\begin{array}{l}- \\
- \\
- \\
- \\
- \\
- \\
- \\
-\end{array}$ & $\begin{array}{l}- \\
- \\
- \\
- \\
- \\
- \\
-\end{array}$ & $\begin{array}{l}3 \\
- \\
1 \\
- \\
- \\
- \\
- \\
1 \\
1\end{array}$ & $\begin{array}{r}10 \\
- \\
- \\
- \\
1 \\
- \\
- \\
5 \\
4\end{array}$ & $\begin{array}{l}- \\
- \\
- \\
- \\
- \\
- \\
-\end{array}$ & $\begin{array}{l}- \\
- \\
- \\
- \\
- \\
- \\
-\end{array}$ & $\begin{array}{r}194 \\
1 \\
27 \\
- \\
1 \\
2 \\
5 \\
6 \\
89 \\
63\end{array}$ & $\begin{array}{r}313 \\
3 \\
61 \\
12 \\
5 \\
1 \\
42 \\
7 \\
41 \\
141\end{array}$ \\
\hline $\begin{array}{l}\text { E.S. CENTRAL } \\
\text { Ky. } \\
\text { Tenn. } \\
\text { Ala. } \\
\text { Miss. }\end{array}$ & $\begin{array}{r}16 \\
1 \\
7 \\
8 \\
-\end{array}$ & $\begin{array}{l}4 \\
- \\
2 \\
1 \\
1\end{array}$ & $\begin{array}{l}- \\
- \\
- \\
-\end{array}$ & $\begin{array}{l}- \\
- \\
- \\
-\end{array}$ & $\begin{array}{l}3 \\
- \\
2 \\
1 \\
-\end{array}$ & $\begin{array}{l}1 \\
- \\
- \\
1\end{array}$ & $\begin{array}{l}- \\
- \\
- \\
-\end{array}$ & $\begin{array}{l}- \\
- \\
- \\
-\end{array}$ & $\begin{array}{r}19 \\
2 \\
12 \\
5 \\
-\end{array}$ & $\begin{array}{r}50 \\
7 \\
19 \\
5 \\
19\end{array}$ \\
\hline $\begin{array}{l}\text { W.S. CENTRAL } \\
\text { Ark. } \\
\text { La. } \\
\text { Okla. } \\
\text { Tex. }\end{array}$ & $\begin{array}{r}10 \\
1 \\
3 \\
6 \\
-\end{array}$ & $\begin{array}{l}9 \\
- \\
- \\
9 \\
-\end{array}$ & $\begin{array}{l}- \\
- \\
- \\
-\end{array}$ & $\begin{array}{l}- \\
- \\
- \\
-\end{array}$ & $\begin{array}{l}1 \\
- \\
1 \\
-\end{array}$ & $\begin{array}{l}4 \\
- \\
- \\
4 \\
-\end{array}$ & $\begin{array}{l}- \\
- \\
- \\
-\end{array}$ & $\begin{array}{l}- \\
- \\
- \\
-\end{array}$ & $\begin{array}{l}6 \\
- \\
4 \\
2 \\
-\end{array}$ & $\begin{array}{r}125 \\
5 \\
4 \\
7 \\
109\end{array}$ \\
\hline $\begin{array}{l}\text { MOUNTAIN } \\
\text { Mont. } \\
\text { Idaho } \\
\text { Wyo. } \\
\text { Colo. } \\
\text { N. Mex. } \\
\text { Ariz. } \\
\text { Utah } \\
\text { Nev. }\end{array}$ & $\begin{array}{r}22 \\
- \\
- \\
- \\
4 \\
2 \\
11 \\
4 \\
1\end{array}$ & $\begin{array}{r}31 \\
- \\
- \\
- \\
7 \\
7 \\
13 \\
3 \\
1\end{array}$ & $\begin{array}{l}1 \\
- \\
- \\
- \\
- \\
- \\
1 \\
- \\
-\end{array}$ & $\begin{array}{l}- \\
- \\
- \\
- \\
- \\
- \\
- \\
-\end{array}$ & $\begin{array}{l}4 \\
- \\
- \\
- \\
1 \\
- \\
1 \\
2 \\
-\end{array}$ & $\begin{array}{l}6 \\
- \\
- \\
- \\
1 \\
2 \\
2 \\
- \\
1\end{array}$ & $\begin{array}{l}- \\
- \\
- \\
- \\
- \\
- \\
- \\
-\end{array}$ & $\begin{array}{l}- \\
- \\
- \\
- \\
- \\
- \\
-\end{array}$ & $\begin{array}{r}33 \\
- \\
- \\
- \\
4 \\
- \\
21 \\
5 \\
3\end{array}$ & $\begin{array}{r}71 \\
2 \\
7 \\
2 \\
13 \\
13 \\
3 \\
24 \\
8 \\
12\end{array}$ \\
\hline $\begin{array}{l}\text { PACIFIC } \\
\text { Wash. } \\
\text { Oreg. } \\
\text { Calif. } \\
\text { Alaska } \\
\text { Hawaii }\end{array}$ & $\begin{array}{r}10 \\
- \\
8 \\
- \\
- \\
2\end{array}$ & $\begin{array}{r}23 \\
- \\
13 \\
4 \\
1 \\
5\end{array}$ & $\begin{array}{l}- \\
- \\
- \\
- \\
-\end{array}$ & $\begin{array}{l}- \\
- \\
- \\
- \\
- \\
-\end{array}$ & $\begin{array}{l}1 \\
- \\
1 \\
- \\
-\end{array}$ & $\begin{array}{l}6 \\
- \\
2 \\
3 \\
1 \\
-\end{array}$ & $\begin{array}{l}- \\
- \\
- \\
- \\
-\end{array}$ & $\begin{array}{l}1 \\
- \\
- \\
1 \\
-\end{array}$ & $\begin{array}{r}106 \\
2 \\
14 \\
87 \\
1 \\
2\end{array}$ & $\begin{array}{r}292 \\
7 \\
20 \\
265 \\
- \\
-\end{array}$ \\
\hline $\begin{array}{l}\text { Guam } \\
\text { P.R. } \\
\text { V.I. } \\
\text { Amer. Samoa } \\
\text { C.N.M.I. }\end{array}$ & $\begin{array}{l}- \\
- \\
\\
-\end{array}$ & $\begin{array}{l}- \\
- \\
\\
U\end{array}$ & $\begin{array}{l}- \\
- \\
\\
-\end{array}$ & $\begin{array}{l}- \\
- \\
\\
U\end{array}$ & $\begin{array}{l}- \\
- \\
\end{array}$ & $\begin{array}{l}- \\
\bar{U} \\
U\end{array}$ & $\begin{array}{l}- \\
\\
\end{array}$ & $\begin{array}{l}- \\
- \\
\\
U\end{array}$ & $\begin{array}{l}- \\
- \\
\end{array}$ & $\begin{array}{r}11 \\
\dot{U} \\
U\end{array}$ \\
\hline
\end{tabular}


TABLE II. (Continued) Provisional cases of selected notifiable diseases, United States, weeks ending February 15, 2003, and February 16, 2002 (7th Week)*

\begin{tabular}{|c|c|c|c|c|c|c|c|c|c|c|}
\hline \multirow[b]{3}{*}{ Reporting area } & \multicolumn{4}{|c|}{ Hepatitis (viral, acute), by type } & \multirow{2}{*}{\multicolumn{2}{|c|}{ Legionellosis }} & \multirow{2}{*}{\multicolumn{2}{|c|}{ Listeriosis }} & \multirow{2}{*}{\multicolumn{2}{|c|}{ Lyme disease }} \\
\hline & \multicolumn{2}{|c|}{ B } & \multicolumn{2}{|c|}{$\mathrm{C}$} & & & & & & \\
\hline & $\begin{array}{l}\text { Cum. } \\
2003\end{array}$ & $\begin{array}{l}\text { Cum. } \\
2002\end{array}$ & $\begin{array}{l}\text { Cum. } \\
2003\end{array}$ & $\begin{array}{l}\text { Cum. } \\
2002\end{array}$ & $\begin{array}{l}\text { Cum. } \\
2003\end{array}$ & $\begin{array}{l}\text { Cum. } \\
2002\end{array}$ & $\begin{array}{l}\text { Cum. } \\
2003\end{array}$ & $\begin{array}{l}\text { Cum. } \\
2002\end{array}$ & $\begin{array}{l}\text { Cum. } \\
2003\end{array}$ & $\begin{array}{l}\text { Cum. } \\
2002\end{array}$ \\
\hline UNITED STATES & 627 & 603 & 102 & 222 & 98 & 97 & 43 & 45 & 354 & 576 \\
\hline $\begin{array}{l}\text { NEW ENGLAND } \\
\text { Maine } \\
\text { N.H. } \\
\text { Vt. } \\
\text { Mass. } \\
\text { R.I. } \\
\text { Conn. }\end{array}$ & $\begin{array}{r}17 \\
- \\
- \\
1 \\
16 \\
- \\
-\end{array}$ & $\begin{array}{r}31 \\
- \\
3 \\
2 \\
22 \\
- \\
4\end{array}$ & $\begin{array}{l}- \\
- \\
- \\
- \\
- \\
-\end{array}$ & $\begin{array}{l}6 \\
- \\
- \\
4 \\
2 \\
- \\
-\end{array}$ & $\begin{array}{l}3 \\
- \\
- \\
1 \\
1 \\
- \\
1\end{array}$ & $\begin{array}{l}5 \\
- \\
1 \\
- \\
2 \\
- \\
2\end{array}$ & $\begin{array}{l}3 \\
- \\
1 \\
- \\
2 \\
- \\
-\end{array}$ & $\begin{array}{l}3 \\
1 \\
- \\
- \\
1 \\
- \\
1\end{array}$ & $\begin{array}{l}4 \\
- \\
- \\
3 \\
- \\
1 \\
-\end{array}$ & $\begin{array}{r}55 \\
- \\
7 \\
- \\
45 \\
3 \\
-\end{array}$ \\
\hline $\begin{array}{l}\text { MID. ATLANTIC } \\
\text { Upstate N.Y. } \\
\text { N.Y. City } \\
\text { N.J. } \\
\text { Pa. }\end{array}$ & $\begin{array}{r}154 \\
5 \\
91 \\
55 \\
3\end{array}$ & $\begin{array}{r}121 \\
4 \\
59 \\
36 \\
22\end{array}$ & $\begin{array}{l}7 \\
3 \\
- \\
4 \\
-\end{array}$ & $\begin{array}{l}7 \\
2 \\
- \\
3 \\
2\end{array}$ & $\begin{array}{r}13 \\
5 \\
8 \\
- \\
-\end{array}$ & $\begin{array}{r}19 \\
4 \\
- \\
6 \\
9\end{array}$ & $\begin{array}{r}10 \\
2 \\
5 \\
2 \\
1\end{array}$ & $\begin{array}{l}5 \\
3 \\
1 \\
- \\
1\end{array}$ & $\begin{array}{r}285 \\
194 \\
55 \\
34 \\
2\end{array}$ & $\begin{array}{r}417 \\
241 \\
89 \\
89 \\
87\end{array}$ \\
\hline $\begin{array}{l}\text { E.N. CENTRAL } \\
\text { Ohio } \\
\text { Ind. } \\
\text { III. } \\
\text { Mich. } \\
\text { Wis. }\end{array}$ & $\begin{array}{r}50 \\
24 \\
- \\
- \\
26\end{array}$ & $\begin{array}{r}50 \\
7 \\
2 \\
3 \\
32 \\
6\end{array}$ & $\begin{array}{r}14 \\
1 \\
- \\
1 \\
12 \\
-\end{array}$ & $\begin{array}{r}10 \\
- \\
- \\
2 \\
8 \\
-\end{array}$ & $\begin{array}{r}28 \\
16 \\
- \\
- \\
12 \\
-\end{array}$ & $\begin{array}{r}37 \\
24 \\
3 \\
- \\
8 \\
2\end{array}$ & $\begin{array}{l}5 \\
2 \\
1 \\
- \\
2 \\
-\end{array}$ & $\begin{array}{l}9 \\
4 \\
- \\
1 \\
1 \\
3\end{array}$ & $\begin{array}{l}6 \\
4 \\
2 \\
- \\
- \\
\end{array}$ & $\begin{array}{r}16 \\
2 \\
1 \\
- \\
- \\
13\end{array}$ \\
\hline $\begin{array}{l}\text { W.N. CENTRAL } \\
\text { Minn. } \\
\text { lowa } \\
\text { Mo. } \\
\text { N. Dak. } \\
\text { S. Dak. } \\
\text { Nebr. } \\
\text { Kans. }\end{array}$ & $\begin{array}{r}21 \\
2 \\
1 \\
13 \\
- \\
- \\
4 \\
1\end{array}$ & $\begin{array}{r}30 \\
1 \\
6 \\
13 \\
- \\
- \\
5 \\
5\end{array}$ & $\begin{array}{r}27 \\
- \\
- \\
25 \\
- \\
- \\
2 \\
-\end{array}$ & $\begin{array}{r}82 \\
- \\
79 \\
- \\
- \\
3 \\
-\end{array}$ & $\begin{array}{l}2 \\
- \\
1 \\
- \\
- \\
- \\
1\end{array}$ & $\begin{array}{l}2 \\
- \\
- \\
1 \\
- \\
- \\
1 \\
-\end{array}$ & $\begin{array}{l}2 \\
1 \\
- \\
- \\
- \\
- \\
1 \\
-\end{array}$ & $\begin{array}{l}1 \\
- \\
- \\
1 \\
- \\
- \\
-\end{array}$ & $\begin{array}{l}- \\
- \\
- \\
- \\
- \\
-\end{array}$ & $\begin{array}{l}7 \\
2 \\
3 \\
2 \\
- \\
- \\
- \\
-\end{array}$ \\
\hline $\begin{array}{l}\text { S. ATLANTIC } \\
\text { Del. } \\
\text { Md. } \\
\text { D.C. } \\
\text { Va. } \\
\text { W.Va. } \\
\text { N.C. } \\
\text { S.C. } \\
\text { Ga. } \\
\text { Fla. }\end{array}$ & $\begin{array}{r}221 \\
1 \\
9 \\
- \\
1 \\
- \\
17 \\
- \\
133 \\
60\end{array}$ & $\begin{array}{r}167 \\
2 \\
18 \\
2 \\
18 \\
2 \\
2 \\
34 \\
3 \\
27 \\
61\end{array}$ & $\begin{array}{r}22 \\
- \\
2 \\
- \\
- \\
- \\
1 \\
- \\
3 \\
16\end{array}$ & $\begin{array}{r}13 \\
3 \\
2 \\
- \\
- \\
- \\
3 \\
1 \\
1 \\
3\end{array}$ & $\begin{array}{r}40 \\
- \\
11 \\
- \\
2 \\
N \\
4 \\
- \\
5 \\
18\end{array}$ & $\begin{array}{r}13 \\
3 \\
5 \\
- \\
- \\
N \\
1 \\
- \\
3 \\
1\end{array}$ & $\begin{array}{r}11 \\
- \\
2 \\
- \\
- \\
- \\
1 \\
1 \\
3 \\
4\end{array}$ & $\begin{array}{l}6 \\
- \\
1 \\
- \\
- \\
- \\
- \\
2 \\
2 \\
1\end{array}$ & $\begin{array}{r}43 \\
31 \\
- \\
- \\
- \\
6 \\
- \\
1 \\
5\end{array}$ & $\begin{array}{r}62 \\
9 \\
45 \\
3 \\
- \\
- \\
- \\
1 \\
- \\
4\end{array}$ \\
\hline $\begin{array}{l}\text { E.S. CENTRAL } \\
\text { Ky. } \\
\text { Tenn. } \\
\text { Ala. } \\
\text { Miss. }\end{array}$ & $\begin{array}{r}28 \\
6 \\
6 \\
9 \\
7\end{array}$ & $\begin{array}{r}48 \\
4 \\
17 \\
14 \\
13\end{array}$ & $\begin{array}{r}13 \\
2 \\
- \\
1 \\
10\end{array}$ & $\begin{array}{r}24 \\
1 \\
3 \\
2 \\
18\end{array}$ & $\begin{array}{l}1 \\
- \\
1 \\
- \\
-\end{array}$ & $\begin{array}{l}1 \\
- \\
- \\
1 \\
-\end{array}$ & $\begin{array}{l}4 \\
- \\
- \\
3 \\
1\end{array}$ & $\begin{array}{l}2 \\
- \\
1 \\
1 \\
-\end{array}$ & $\begin{array}{l}1 \\
- \\
1 \\
- \\
-\end{array}$ & $\begin{array}{l}2 \\
- \\
- \\
-\end{array}$ \\
\hline $\begin{array}{l}\text { W.S. CENTRAL } \\
\text { Ark. } \\
\text { La. } \\
\text { Okla. } \\
\text { Tex. }\end{array}$ & $\begin{array}{r}10 \\
- \\
10 \\
- \\
-\end{array}$ & $\begin{array}{r}21 \\
17 \\
3 \\
1 \\
-\end{array}$ & $\begin{array}{l}6 \\
- \\
6 \\
- \\
-\end{array}$ & $\begin{array}{r}61 \\
4 \\
1 \\
- \\
56\end{array}$ & $\begin{array}{l}2 \\
- \\
- \\
2 \\
-\end{array}$ & $\begin{array}{l}2 \\
- \\
- \\
5\end{array}$ & $\begin{array}{l}- \\
- \\
- \\
-\end{array}$ & $\begin{array}{l}4 \\
- \\
- \\
- \\
4\end{array}$ & $\begin{array}{l}2 \\
- \\
2 \\
- \\
-\end{array}$ & $\begin{array}{l}8 \\
- \\
1 \\
- \\
7\end{array}$ \\
\hline $\begin{array}{l}\text { MOUNTAIN } \\
\text { Mont. } \\
\text { Idaho } \\
\text { Wyo. } \\
\text { Colo. } \\
\text { N. Mex. } \\
\text { Ariz. } \\
\text { Utah } \\
\text { Nev. }\end{array}$ & $\begin{array}{r}69 \\
2 \\
- \\
1 \\
12 \\
- \\
49 \\
4 \\
1\end{array}$ & $\begin{array}{r}38 \\
- \\
- \\
3 \\
10 \\
10 \\
7 \\
3 \\
5\end{array}$ & $\begin{array}{l}7 \\
- \\
- \\
5 \\
5 \\
- \\
2 \\
- \\
-\end{array}$ & $\begin{array}{l}5 \\
- \\
- \\
2 \\
1 \\
- \\
- \\
- \\
2\end{array}$ & $\begin{array}{l}5 \\
- \\
1 \\
- \\
1 \\
- \\
2 \\
1 \\
-\end{array}$ & $\begin{array}{l}4 \\
- \\
- \\
- \\
1 \\
1 \\
- \\
2 \\
-\end{array}$ & $\begin{array}{l}8 \\
1 \\
- \\
- \\
5 \\
- \\
2 \\
- \\
-\end{array}$ & $\begin{array}{l}3 \\
- \\
- \\
- \\
1 \\
- \\
2 \\
- \\
-\end{array}$ & $\begin{array}{l}1 \\
- \\
1 \\
- \\
- \\
- \\
- \\
-\end{array}$ & $\begin{array}{l}1 \\
- \\
- \\
- \\
- \\
1 \\
- \\
- \\
-\end{array}$ \\
\hline $\begin{array}{l}\text { PACIFIC } \\
\text { Wash. } \\
\text { Oreg. } \\
\text { Calif. } \\
\text { Alaska } \\
\text { Hawaii }\end{array}$ & $\begin{array}{r}57 \\
3 \\
17 \\
37 \\
- \\
-\end{array}$ & $\begin{array}{r}97 \\
5 \\
20 \\
71 \\
1 \\
-\end{array}$ & $\begin{array}{l}6 \\
1 \\
2 \\
3 \\
- \\
-\end{array}$ & $\begin{array}{r}14 \\
1 \\
6 \\
7 \\
- \\
-\end{array}$ & $\begin{array}{l}4 \\
- \\
N \\
4 \\
- \\
-\end{array}$ & $\begin{array}{r}14 \\
- \\
N \\
14 \\
- \\
-\end{array}$ & $\begin{array}{l}- \\
- \\
- \\
- \\
- \\
-\end{array}$ & $\begin{array}{r}12 \\
- \\
1 \\
11 \\
- \\
-\end{array}$ & $\begin{array}{r}12 \\
- \\
3 \\
9 \\
- \\
\mathrm{N}\end{array}$ & $\begin{array}{c}8 \\
- \\
1 \\
7 \\
- \\
\mathrm{N}\end{array}$ \\
\hline $\begin{array}{l}\text { Guam } \\
\text { P.R. } \\
\text { V.I. } \\
\text { Amer. Samoa } \\
\text { C.N.M.I. }\end{array}$ & $\begin{array}{l}- \\
- \\
\end{array}$ & $\begin{array}{l}\overline{4} \\
\bar{U} \\
U\end{array}$ & $\begin{array}{l}- \\
- \\
\\
-\end{array}$ & $\begin{array}{l}- \\
- \\
\\
U\end{array}$ & $\begin{array}{l}- \\
- \\
\end{array}$ & $\begin{array}{l}- \\
- \\
\\
U\end{array}$ & $\begin{array}{l}- \\
\bar{U} \\
\end{array}$ & $\begin{array}{l}- \\
1 \\
\\
U\end{array}$ & $\begin{array}{c}\bar{N} \\
\bar{U} \\
-\end{array}$ & $\begin{array}{l}- \\
\mathrm{N} \\
\bar{U} \\
\mathrm{U}\end{array}$ \\
\hline
\end{tabular}

$\mathrm{N}:$ Not notifiable. 
TABLE II. (Continued) Provisional cases of selected notifiable diseases, United States, weeks ending February 15, 2003, and February 16, 2002 (7th Week)*

\begin{tabular}{|c|c|c|c|c|c|c|c|c|c|c|}
\hline \multirow[b]{2}{*}{ Reporting area } & \multicolumn{2}{|c|}{ Malaria } & \multicolumn{2}{|c|}{$\begin{array}{c}\text { Meningococcal } \\
\text { disease }\end{array}$} & \multicolumn{2}{|c|}{ Pertussis } & \multicolumn{2}{|c|}{ Rabies, animal } & \multicolumn{2}{|c|}{$\begin{array}{c}\text { Rocky Mountain } \\
\text { spotted fever }\end{array}$} \\
\hline & $\begin{array}{l}\text { Cum. } \\
2003 \\
\end{array}$ & $\begin{array}{l}\text { Cum. } \\
2002 \\
\end{array}$ & $\begin{array}{l}\text { Cum. } \\
2003 \\
\end{array}$ & $\begin{array}{l}\text { Cum. } \\
2002 \\
\end{array}$ & $\begin{array}{l}\text { Cum. } \\
2003 \\
\end{array}$ & $\begin{array}{l}\text { Cum. } \\
2002 \\
\end{array}$ & $\begin{array}{l}\text { Cum. } \\
2003 \\
\end{array}$ & $\begin{array}{l}\text { Cum. } \\
2002 \\
\end{array}$ & $\begin{array}{l}\text { Cum. } \\
2003 \\
\end{array}$ & $\begin{array}{l}\text { Cum. } \\
2002 \\
\end{array}$ \\
\hline UNITED STATES & 93 & 131 & 153 & 254 & 413 & 662 & 363 & 650 & 26 & 33 \\
\hline $\begin{array}{l}\text { NEW ENGLAND } \\
\text { Maine } \\
\text { N.H. } \\
\text { Vt. } \\
\text { Mass. } \\
\text { R.I. } \\
\text { Conn. }\end{array}$ & $\begin{array}{l}2 \\
1 \\
1 \\
- \\
- \\
- \\
-\end{array}$ & $\begin{array}{r}12 \\
1 \\
4 \\
- \\
4 \\
- \\
3\end{array}$ & $\begin{array}{l}7 \\
1 \\
- \\
- \\
5 \\
- \\
1\end{array}$ & $\begin{array}{r}19 \\
2 \\
1 \\
2 \\
11 \\
2 \\
1\end{array}$ & $\begin{array}{r}85 \\
- \\
- \\
16 \\
69 \\
- \\
-\end{array}$ & $\begin{array}{r}138 \\
3 \\
1 \\
19 \\
110 \\
- \\
5\end{array}$ & $\begin{array}{r}50 \\
4 \\
2 \\
3 \\
18 \\
- \\
23\end{array}$ & $\begin{array}{r}64 \\
4 \\
1 \\
17 \\
19 \\
4 \\
19\end{array}$ & $\begin{array}{l}1 \\
- \\
- \\
1 \\
- \\
-\end{array}$ & $\begin{array}{l}- \\
- \\
- \\
- \\
- \\
-\end{array}$ \\
\hline $\begin{array}{l}\text { MID. ATLANTIC } \\
\text { Upstate N.Y. } \\
\text { N.Y. City } \\
\text { N.J. } \\
\text { Pa. }\end{array}$ & $\begin{array}{r}34 \\
4 \\
28 \\
2 \\
-\end{array}$ & $\begin{array}{r}21 \\
3 \\
7 \\
9 \\
2\end{array}$ & $\begin{array}{r}12 \\
3 \\
7 \\
1 \\
1\end{array}$ & $\begin{array}{r}28 \\
6 \\
5 \\
6 \\
11\end{array}$ & $\begin{array}{r}30 \\
28 \\
- \\
2 \\
-\end{array}$ & $\begin{array}{r}35 \\
26 \\
4 \\
- \\
5\end{array}$ & $\begin{array}{r}37 \\
34 \\
1 \\
- \\
2\end{array}$ & $\begin{array}{r}85 \\
54 \\
4 \\
14 \\
13\end{array}$ & $\begin{array}{l}1 \\
- \\
1 \\
-\end{array}$ & $\begin{array}{l}4 \\
- \\
- \\
4\end{array}$ \\
\hline $\begin{array}{l}\text { E.N. CENTRAL } \\
\text { Ohio } \\
\text { Ind. } \\
\text { III. } \\
\text { Mich. } \\
\text { Wis. }\end{array}$ & $\begin{array}{l}6 \\
3 \\
- \\
1 \\
2 \\
-\end{array}$ & $\begin{array}{r}18 \\
7 \\
- \\
6 \\
4 \\
1\end{array}$ & $\begin{array}{r}26 \\
11 \\
4 \\
- \\
8 \\
3\end{array}$ & $\begin{array}{r}39 \\
16 \\
6 \\
5 \\
7 \\
5\end{array}$ & $\begin{array}{r}49 \\
44 \\
- \\
- \\
4 \\
1\end{array}$ & $\begin{array}{r}90 \\
50 \\
3 \\
11 \\
11 \\
15\end{array}$ & $\begin{array}{l}4 \\
- \\
2 \\
- \\
2 \\
-\end{array}$ & $\begin{array}{l}2 \\
1 \\
1 \\
- \\
- \\
-\end{array}$ & $\begin{array}{l}1 \\
1 \\
- \\
- \\
-\end{array}$ & $\begin{array}{l}2 \\
2 \\
- \\
- \\
- \\
-\end{array}$ \\
\hline $\begin{array}{l}\text { W.N. CENTRAL } \\
\text { Minn. } \\
\text { lowa } \\
\text { Mo. } \\
\text { N. Dak. } \\
\text { S. Dak. } \\
\text { Nebr. } \\
\text { Kans. }\end{array}$ & $\begin{array}{l}4 \\
2 \\
2 \\
- \\
- \\
- \\
- \\
-\end{array}$ & $\begin{array}{l}8 \\
- \\
2 \\
2 \\
- \\
- \\
2 \\
2\end{array}$ & $\begin{array}{r}10 \\
1 \\
4 \\
4 \\
- \\
- \\
- \\
1\end{array}$ & $\begin{array}{r}14 \\
- \\
3 \\
6 \\
- \\
2 \\
2 \\
1\end{array}$ & $\begin{array}{r}14 \\
- \\
1 \\
7 \\
- \\
1 \\
- \\
5\end{array}$ & $\begin{array}{r}61 \\
1 \\
22 \\
23 \\
- \\
2 \\
2 \\
11\end{array}$ & $\begin{array}{r}52 \\
4 \\
5 \\
- \\
8 \\
- \\
- \\
35\end{array}$ & $\begin{array}{r}39 \\
3 \\
4 \\
1 \\
- \\
15 \\
- \\
16\end{array}$ & $\begin{array}{l}1 \\
- \\
1 \\
- \\
- \\
- \\
-\end{array}$ & $\begin{array}{l}1 \\
- \\
- \\
1 \\
- \\
- \\
-\end{array}$ \\
\hline $\begin{array}{l}\text { S. ATLANTIC } \\
\text { Del. } \\
\text { Md. } \\
\text { D.C. } \\
\text { Va. } \\
\text { W.Va. } \\
\text { N.C. } \\
\text { S.C. } \\
\text { Ga. } \\
\text { Fla. }\end{array}$ & $\begin{array}{r}27 \\
12 \\
- \\
- \\
1 \\
4 \\
- \\
3 \\
7\end{array}$ & $\begin{array}{r}34 \\
- \\
14 \\
2 \\
- \\
- \\
4 \\
2 \\
11 \\
1\end{array}$ & $\begin{array}{r}40 \\
4 \\
3 \\
- \\
2 \\
- \\
4 \\
- \\
6 \\
21\end{array}$ & $\begin{array}{r}35 \\
1 \\
1 \\
- \\
2 \\
- \\
5 \\
2 \\
7 \\
17\end{array}$ & $\begin{array}{r}60 \\
12 \\
- \\
1 \\
- \\
27 \\
- \\
14 \\
6\end{array}$ & $\begin{array}{r}38 \\
1 \\
7 \\
- \\
12 \\
- \\
7 \\
10 \\
- \\
1\end{array}$ & $\begin{array}{r}184 \\
- \\
2 \\
- \\
47 \\
7 \\
66 \\
13 \\
36 \\
13\end{array}$ & $\begin{array}{r}188 \\
3 \\
48 \\
- \\
54 \\
18 \\
54 \\
6 \\
- \\
5\end{array}$ & $\begin{array}{r}20 \\
- \\
- \\
- \\
- \\
16 \\
- \\
- \\
-\end{array}$ & $\begin{array}{r}23 \\
- \\
5 \\
- \\
- \\
- \\
18 \\
- \\
- \\
-\end{array}$ \\
\hline $\begin{array}{l}\text { E.S. CENTRAL } \\
\text { Ky. } \\
\text { Tenn. } \\
\text { Ala. } \\
\text { Miss. }\end{array}$ & $\begin{array}{l}3 \\
- \\
1 \\
2 \\
-\end{array}$ & $\begin{array}{l}3 \\
- \\
1 \\
1 \\
1\end{array}$ & $\begin{array}{l}9 \\
- \\
3 \\
3 \\
3\end{array}$ & $\begin{array}{r}10 \\
- \\
1 \\
8 \\
1\end{array}$ & $\begin{array}{r}14 \\
3 \\
4 \\
7 \\
-\end{array}$ & $\begin{array}{r}23 \\
6 \\
10 \\
1 \\
6\end{array}$ & $\begin{array}{l}4 \\
3 \\
- \\
1 \\
-\end{array}$ & $\begin{array}{r}109 \\
1 \\
108 \\
- \\
-\end{array}$ & $\begin{array}{l}1 \\
- \\
1 \\
- \\
-\end{array}$ & $\begin{array}{l}2 \\
- \\
2 \\
- \\
-\end{array}$ \\
\hline $\begin{array}{l}\text { W.S. CENTRAL } \\
\text { Ark. } \\
\text { La. } \\
\text { Okla. } \\
\text { Tex. }\end{array}$ & $\begin{array}{l}1 \\
- \\
1 \\
- \\
-\end{array}$ & $\begin{array}{l}1 \\
- \\
1 \\
- \\
-\end{array}$ & $\begin{array}{r}11 \\
1 \\
7 \\
3 \\
-\end{array}$ & $\begin{array}{r}40 \\
5 \\
3 \\
4 \\
28\end{array}$ & $\begin{array}{l}- \\
- \\
- \\
-\end{array}$ & $\begin{array}{r}111 \\
93 \\
- \\
2 \\
16\end{array}$ & $\begin{array}{r}10 \\
- \\
10 \\
-\end{array}$ & $\begin{array}{r}122 \\
- \\
- \\
16 \\
106\end{array}$ & $\begin{array}{l}- \\
- \\
- \\
-\end{array}$ & $\begin{array}{l}1 \\
- \\
- \\
- \\
1\end{array}$ \\
\hline $\begin{array}{l}\text { MOUNTAIN } \\
\text { Mont. } \\
\text { Idaho } \\
\text { Wyo. } \\
\text { Colo. } \\
\text { N. Mex. } \\
\text { Ariz. } \\
\text { Utah } \\
\text { Nev. }\end{array}$ & $\begin{array}{l}3 \\
- \\
- \\
- \\
2 \\
- \\
1 \\
- \\
-\end{array}$ & $\begin{array}{l}4 \\
- \\
- \\
- \\
2 \\
- \\
- \\
1 \\
1\end{array}$ & $\begin{array}{l}5 \\
- \\
- \\
- \\
1 \\
1 \\
3 \\
- \\
-\end{array}$ & $\begin{array}{r}19 \\
- \\
- \\
- \\
6 \\
- \\
7 \\
1 \\
5\end{array}$ & $\begin{array}{r}108 \\
- \\
2 \\
51 \\
10 \\
35 \\
7 \\
3\end{array}$ & $\begin{array}{r}82 \\
2 \\
5 \\
2 \\
45 \\
13 \\
9 \\
5 \\
1\end{array}$ & $\begin{array}{r}10 \\
1 \\
- \\
- \\
- \\
- \\
9 \\
- \\
-\end{array}$ & $\begin{array}{r}15 \\
- \\
- \\
1 \\
- \\
- \\
14 \\
- \\
-\end{array}$ & $\begin{array}{l}- \\
- \\
- \\
- \\
- \\
- \\
-\end{array}$ & $\begin{array}{l}- \\
- \\
- \\
- \\
- \\
- \\
- \\
-\end{array}$ \\
\hline $\begin{array}{l}\text { PACIFIC } \\
\text { Wash. } \\
\text { Oreg. } \\
\text { Calif. } \\
\text { Alaska } \\
\text { Hawaii }\end{array}$ & $\begin{array}{r}13 \\
4 \\
5 \\
4 \\
- \\
-\end{array}$ & $\begin{array}{r}30 \\
- \\
- \\
27 \\
1 \\
2\end{array}$ & $\begin{array}{r}33 \\
2 \\
9 \\
21 \\
- \\
1\end{array}$ & $\begin{array}{r}50 \\
7 \\
11 \\
30 \\
1 \\
1\end{array}$ & $\begin{array}{r}53 \\
15 \\
32 \\
6 \\
-\end{array}$ & $\begin{array}{r}84 \\
4 \\
11 \\
65 \\
1 \\
3\end{array}$ & $\begin{array}{r}12 \\
- \\
12 \\
- \\
-\end{array}$ & $\begin{array}{r}26 \\
- \\
12 \\
14 \\
-\end{array}$ & $\begin{array}{l}1 \\
- \\
1 \\
-\end{array}$ & $\begin{array}{l}- \\
- \\
- \\
- \\
-\end{array}$ \\
\hline $\begin{array}{l}\text { Guam } \\
\text { P.R. } \\
\text { V.I. } \\
\text { Amer. Samoa } \\
\text { C.N.M.I. }\end{array}$ & $\begin{array}{l}- \\
- \\
\\
-\end{array}$ & $\begin{array}{l}- \\
- \\
\\
U\end{array}$ & $\begin{array}{l}- \\
- \\
\\
-\end{array}$ & $\begin{array}{l}- \\
1 \\
\\
U\end{array}$ & $\begin{array}{l}- \\
- \\
\\
-\end{array}$ & $\begin{array}{l}- \\
- \\
\\
U\end{array}$ & $\begin{array}{l}- \\
- \\
\\
-\end{array}$ & $\begin{array}{r}12 \\
\dot{U} \\
\dot{U}\end{array}$ & $\begin{array}{l}- \\
\end{array}$ & $\begin{array}{l}- \\
- \\
\\
U\end{array}$ \\
\hline
\end{tabular}


TABLE II. (Continued) Provisional cases of selected notifiable diseases, United States, weeks ending February 15, 2003, and February 16, 2002 (7th Week)*

\begin{tabular}{|c|c|c|c|c|c|c|c|c|c|c|}
\hline \multirow[b]{3}{*}{ Reporting area } & \multirow{2}{*}{\multicolumn{2}{|c|}{ Salmonellosis }} & \multirow{2}{*}{\multicolumn{2}{|c|}{ Shigellosis }} & \multirow{2}{*}{\multicolumn{2}{|c|}{$\begin{array}{c}\text { Streptococcal disease, } \\
\text { invasive, group A }\end{array}$}} & \multicolumn{4}{|c|}{ Streptococcus pneumoniae, invasive } \\
\hline & & & & & & & \multicolumn{2}{|c|}{$\begin{array}{l}\text { Drug resistant, } \\
\text { all ages }\end{array}$} & \multicolumn{2}{|c|}{ Age $<5$ years } \\
\hline & $\begin{array}{l}\text { Cum. } \\
2003\end{array}$ & $\begin{array}{l}\text { Cum. } \\
2002 \\
\end{array}$ & $\begin{array}{l}\text { Cum. } \\
2003 \\
\end{array}$ & $\begin{array}{l}\text { Cum. } \\
2002 \\
\end{array}$ & $\begin{array}{l}\text { Cum. } \\
2003 \\
\end{array}$ & $\begin{array}{l}\text { Cum. } \\
2002 \\
\end{array}$ & $\begin{array}{l}\text { Cum. } \\
2003 \\
\end{array}$ & $\begin{array}{l}\text { Cum. } \\
2002 \\
\end{array}$ & $\begin{array}{l}\text { Cum. } \\
2003 \\
\end{array}$ & $\begin{array}{l}\text { Cum } \\
2002 \\
\end{array}$ \\
\hline UNITED STATES & 2,464 & 3,513 & 1,895 & 1,855 & 459 & 582 & 281 & 217 & 50 & 17 \\
\hline $\begin{array}{l}\text { NEW ENGLAND } \\
\text { Maine } \\
\text { N.H. } \\
\text { Vt. } \\
\text { Mass. } \\
\text { R.I. } \\
\text { Conn. }\end{array}$ & $\begin{array}{r}97 \\
5 \\
4 \\
3 \\
59 \\
5 \\
21\end{array}$ & $\begin{array}{r}160 \\
28 \\
4 \\
7 \\
87 \\
5 \\
29\end{array}$ & $\begin{array}{r}31 \\
1 \\
- \\
- \\
19 \\
2 \\
9\end{array}$ & $\begin{array}{r}33 \\
2 \\
1 \\
- \\
26 \\
- \\
4\end{array}$ & $\begin{array}{r}12 \\
- \\
1 \\
2 \\
9 \\
- \\
-\end{array}$ & $\begin{array}{r}24 \\
4 \\
4 \\
1 \\
15 \\
- \\
-\end{array}$ & $\begin{array}{l}2 \\
- \\
- \\
2 \\
N \\
- \\
-\end{array}$ & $\begin{array}{l}1 \\
- \\
- \\
1 \\
N \\
- \\
-\end{array}$ & $\begin{array}{l}- \\
- \\
N \\
- \\
N \\
- \\
-\end{array}$ & $\begin{array}{c}1 \\
- \\
\mathrm{N} \\
1 \\
\mathrm{~N} \\
- \\
-\end{array}$ \\
\hline $\begin{array}{l}\text { MID. ATLANTIC } \\
\text { Upstate N.Y. } \\
\text { N.Y. City } \\
\text { N.J. } \\
\text { Pa. }\end{array}$ & $\begin{array}{r}246 \\
41 \\
184 \\
11 \\
10\end{array}$ & $\begin{array}{r}361 \\
48 \\
103 \\
126 \\
84\end{array}$ & $\begin{array}{r}119 \\
26 \\
79 \\
5 \\
9\end{array}$ & $\begin{array}{r}77 \\
7 \\
36 \\
18 \\
16\end{array}$ & $\begin{array}{r}59 \\
39 \\
15 \\
1 \\
4\end{array}$ & $\begin{array}{r}87 \\
30 \\
27 \\
26 \\
4\end{array}$ & $\begin{array}{r}7 \\
7 \\
\text { U } \\
\mathrm{N} \\
-\end{array}$ & $\begin{array}{r}12 \\
12 \\
\mathrm{U} \\
\mathrm{N} \\
-\end{array}$ & $\begin{array}{r}12 \\
12 \\
\mathrm{U} \\
\mathrm{N} \\
-\end{array}$ & $\begin{array}{r}3 \\
3 \\
U \\
N \\
-\end{array}$ \\
\hline $\begin{array}{l}\text { E.N. CENTRAL } \\
\text { Ohio } \\
\text { Ind. } \\
\text { III. } \\
\text { Mich. } \\
\text { Wis. }\end{array}$ & $\begin{array}{r}342 \\
152 \\
26 \\
75 \\
64 \\
25\end{array}$ & $\begin{array}{r}600 \\
106 \\
33 \\
307 \\
89 \\
65\end{array}$ & $\begin{array}{r}127 \\
45 \\
8 \\
39 \\
30 \\
5\end{array}$ & $\begin{array}{r}261 \\
132 \\
6 \\
89 \\
20 \\
14\end{array}$ & $\begin{array}{r}120 \\
50 \\
7 \\
1 \\
61 \\
1\end{array}$ & $\begin{array}{r}150 \\
28 \\
3 \\
44 \\
49 \\
26\end{array}$ & $\begin{array}{r}65 \\
56 \\
9 \\
- \\
- \\
\mathrm{N}\end{array}$ & $\begin{array}{r}17 \\
- \\
15 \\
2 \\
- \\
\mathrm{N}\end{array}$ & $\begin{array}{r}28 \\
26 \\
2 \\
- \\
\mathrm{N} \\
-\end{array}$ & $\begin{array}{r}12 \\
- \\
2 \\
- \\
N \\
10\end{array}$ \\
\hline $\begin{array}{l}\text { W.N. CENTRAL } \\
\text { Minn. } \\
\text { lowa } \\
\text { Mo. } \\
\text { N. Dak. } \\
\text { S. Dak. } \\
\text { Nebr. } \\
\text { Kans. }\end{array}$ & $\begin{array}{r}166 \\
50 \\
48 \\
34 \\
2 \\
5 \\
11 \\
16\end{array}$ & $\begin{array}{r}239 \\
46 \\
35 \\
109 \\
- \\
11 \\
12 \\
26\end{array}$ & $\begin{array}{r}106 \\
9 \\
3 \\
25 \\
- \\
8 \\
49 \\
12\end{array}$ & $\begin{array}{r}199 \\
21 \\
11 \\
23 \\
- \\
91 \\
38 \\
15\end{array}$ & $\begin{array}{r}42 \\
17 \\
- \\
5 \\
1 \\
5 \\
8 \\
6\end{array}$ & $\begin{array}{r}25 \\
- \\
- \\
12 \\
- \\
- \\
6 \\
7\end{array}$ & $\begin{array}{r}41 \\
- \\
\mathrm{N} \\
1 \\
1 \\
- \\
8 \\
31\end{array}$ & $\begin{array}{r}37 \\
- \\
\mathrm{N} \\
1 \\
- \\
1 \\
9 \\
26\end{array}$ & $\begin{array}{r}5 \\
5 \\
\mathrm{~N} \\
- \\
- \\
- \\
\mathrm{N} \\
\mathrm{N}\end{array}$ & $\begin{array}{l}- \\
- \\
N \\
- \\
- \\
- \\
N \\
N\end{array}$ \\
\hline $\begin{array}{l}\text { S. ATLANTIC } \\
\text { Del. } \\
\text { Md. } \\
\text { D.C. } \\
\text { Va. } \\
\text { W. Va. } \\
\text { N.C. } \\
\text { S.C. } \\
\text { Ga. } \\
\text { Fla. }\end{array}$ & $\begin{array}{r}864 \\
2 \\
78 \\
- \\
45 \\
1 \\
169 \\
39 \\
219 \\
311\end{array}$ & $\begin{array}{r}1,023 \\
10 \\
70 \\
9 \\
71 \\
4 \\
118 \\
31 \\
282 \\
428\end{array}$ & $\begin{array}{r}1,090 \\
50 \\
107 \\
- \\
29 \\
- \\
119 \\
14 \\
416 \\
355\end{array}$ & $\begin{array}{r}707 \\
2 \\
52 \\
3 \\
154 \\
1 \\
37 \\
6 \\
307 \\
145\end{array}$ & $\begin{array}{r}94 \\
1 \\
34 \\
- \\
- \\
- \\
17 \\
1 \\
13 \\
28\end{array}$ & $\begin{array}{r}98 \\
- \\
13 \\
2 \\
6 \\
- \\
23 \\
2 \\
39 \\
13\end{array}$ & $\begin{array}{r}141 \\
- \\
- \\
- \\
\mathrm{N} \\
7 \\
\mathrm{~N} \\
9 \\
35 \\
90\end{array}$ & $\begin{array}{r}113 \\
3 \\
- \\
3 \\
N \\
3 \\
N \\
21 \\
48 \\
35\end{array}$ & $\begin{array}{l}- \\
\mathrm{N} \\
- \\
- \\
\mathrm{N} \\
- \\
\mathrm{U} \\
\mathrm{N} \\
\mathrm{N} \\
\mathrm{N}\end{array}$ & $\begin{array}{l}1 \\
\mathrm{~N} \\
- \\
1 \\
\mathrm{~N} \\
- \\
\mathrm{U} \\
\mathrm{N} \\
\mathrm{N} \\
\mathrm{N}\end{array}$ \\
\hline $\begin{array}{l}\text { E.S. CENTRAL } \\
\text { Ky. } \\
\text { Tenn. } \\
\text { Ala. } \\
\text { Miss. }\end{array}$ & $\begin{array}{r}202 \\
35 \\
61 \\
73 \\
33\end{array}$ & $\begin{array}{r}182 \\
19 \\
49 \\
62 \\
52\end{array}$ & $\begin{array}{r}101 \\
12 \\
26 \\
49 \\
14\end{array}$ & $\begin{array}{r}123 \\
30 \\
9 \\
36 \\
48\end{array}$ & $\begin{array}{r}15 \\
2 \\
13 \\
- \\
-\end{array}$ & $\begin{array}{r}16 \\
3 \\
13 \\
- \\
-\end{array}$ & $\begin{array}{l}9 \\
- \\
9 \\
- \\
-\end{array}$ & $\begin{array}{r}25 \\
3 \\
22 \\
- \\
-\end{array}$ & $\begin{array}{l}- \\
\mathrm{N} \\
\mathrm{N} \\
\mathrm{N} \\
-\end{array}$ & $\begin{array}{l}- \\
N \\
N \\
N \\
-\end{array}$ \\
\hline $\begin{array}{l}\text { W.S. CENTRAL } \\
\text { Ark. } \\
\text { La. } \\
\text { Okla. } \\
\text { Tex. }\end{array}$ & $\begin{array}{r}61 \\
25 \\
14 \\
22 \\
-\end{array}$ & $\begin{array}{r}201 \\
34 \\
17 \\
24 \\
126\end{array}$ & $\begin{array}{r}86 \\
1 \\
15 \\
70 \\
-\end{array}$ & $\begin{array}{r}127 \\
18 \\
11 \\
27 \\
71\end{array}$ & $\begin{array}{r}12 \\
1 \\
- \\
11 \\
-\end{array}$ & $\begin{array}{r}44 \\
- \\
- \\
6 \\
38\end{array}$ & $\begin{array}{r}12 \\
1 \\
11 \\
\mathrm{~N} \\
\mathrm{~N}\end{array}$ & $\begin{array}{l}4 \\
2 \\
2 \\
N \\
N\end{array}$ & $\begin{array}{l}5 \\
- \\
3 \\
2 \\
-\end{array}$ & $\begin{array}{l}- \\
- \\
- \\
-\end{array}$ \\
\hline $\begin{array}{l}\text { MOUNTAIN } \\
\text { Mont. } \\
\text { Idaho } \\
\text { Wyo. } \\
\text { Colo. } \\
\text { N. Mex. } \\
\text { Ariz. } \\
\text { Utah } \\
\text { Nev. }\end{array}$ & $\begin{array}{r}162 \\
4 \\
11 \\
3 \\
45 \\
13 \\
62 \\
16 \\
8\end{array}$ & $\begin{array}{r}190 \\
3 \\
10 \\
5 \\
67 \\
26 \\
33 \\
16 \\
30\end{array}$ & $\begin{array}{r}101 \\
- \\
1 \\
1 \\
17 \\
13 \\
64 \\
3 \\
2\end{array}$ & $\begin{array}{r}46 \\
- \\
2 \\
- \\
15 \\
3 \\
14 \\
5 \\
7\end{array}$ & $\begin{array}{r}81 \\
- \\
4 \\
- \\
25 \\
12 \\
38 \\
2 \\
-\end{array}$ & $\begin{array}{r}43 \\
- \\
1 \\
1 \\
19 \\
19 \\
- \\
3 \\
-\end{array}$ & $\begin{array}{r}4 \\
- \\
\mathrm{N} \\
1 \\
- \\
3 \\
- \\
- \\
-\end{array}$ & $\begin{array}{l}8 \\
- \\
N \\
5 \\
- \\
3 \\
- \\
- \\
-\end{array}$ & $\begin{array}{c}- \\
- \\
\mathrm{N} \\
- \\
- \\
- \\
\mathrm{N} \\
- \\
-\end{array}$ & $\begin{array}{r}- \\
- \\
\mathrm{N} \\
- \\
- \\
- \\
\mathrm{N} \\
- \\
-\end{array}$ \\
\hline $\begin{array}{l}\text { PACIFIC } \\
\text { Wash. } \\
\text { Oreg. } \\
\text { Calif. } \\
\text { Alaska } \\
\text { Hawaii }\end{array}$ & $\begin{array}{r}324 \\
30 \\
27 \\
235 \\
13 \\
19\end{array}$ & $\begin{array}{r}557 \\
13 \\
39 \\
465 \\
10 \\
30\end{array}$ & $\begin{array}{r}134 \\
6 \\
8 \\
112 \\
2 \\
6\end{array}$ & $\begin{array}{r}282 \\
3 \\
20 \\
250 \\
1 \\
8\end{array}$ & $\begin{array}{r}24 \\
- \\
N \\
10 \\
- \\
14\end{array}$ & $\begin{array}{r}95 \\
16 \\
N \\
65 \\
- \\
14\end{array}$ & $\begin{array}{r}- \\
- \\
N \\
N \\
-\end{array}$ & $\begin{array}{r}- \\
- \\
N \\
N \\
-\end{array}$ & $\begin{array}{l}- \\
N \\
N \\
N \\
-\end{array}$ & $\begin{array}{l}- \\
N \\
N \\
N \\
N\end{array}$ \\
\hline $\begin{array}{l}\text { Guam } \\
\text { P.R. } \\
\text { V.I. } \\
\text { Amer. Samoa } \\
\text { C.N.M.I. }\end{array}$ & $\begin{array}{l}- \\
1 \\
- \\
-\end{array}$ & $\begin{array}{r}- \\
16 \\
\dot{U} \\
U\end{array}$ & $\begin{array}{l}- \\
- \\
\text { U }\end{array}$ & $\begin{array}{l}- \\
1 \\
- \\
U\end{array}$ & $\begin{array}{c}\bar{N} \\
- \\
\\
-\end{array}$ & $\begin{array}{r}- \\
\text { N } \\
\\
U\end{array}$ & $\begin{array}{l}- \\
- \\
\end{array}$ & $\begin{array}{l}- \\
- \\
U \\
U\end{array}$ & $\begin{array}{c}\bar{N} \\
\bar{U} \\
-\end{array}$ & $\begin{array}{c}\bar{N} \\
\bar{U} \\
U\end{array}$ \\
\hline
\end{tabular}

\footnotetext{
$\mathrm{N}$ : Not notifiable. U: Unavailable. $\quad$ - : No reported cases.
}

${ }^{*}$ Incidence data for reporting years 2002 and 2003 are provisional and cumulative (year-to-date). 
TABLE II. (Continued) Provisional cases of selected notifiable diseases, United States, weeks ending February 15, 2003, and February 16, 2002 (7th Week)*

\begin{tabular}{|c|c|c|c|c|c|c|c|c|c|}
\hline \multirow[b]{3}{*}{ Reporting area } & \multicolumn{4}{|c|}{ Syphilis } & \multirow{2}{*}{\multicolumn{2}{|c|}{ Tuberculosis }} & \multirow{2}{*}{\multicolumn{2}{|c|}{ Typhoid fever }} & \multirow{3}{*}{$\begin{array}{c}\begin{array}{c}\text { Varicella } \\
\text { (Chickenpox) }\end{array} \\
\text { Cum. } \\
2003 \\
\end{array}$} \\
\hline & \multicolumn{2}{|c|}{ Primary \& secondary } & \multicolumn{2}{|c|}{ Congenital } & & & & & \\
\hline & $\begin{array}{l}\text { Cum. } \\
2003 \\
\end{array}$ & $\begin{array}{l}\text { Cum. } \\
2002 \\
\end{array}$ & $\begin{array}{l}\text { Cum. } \\
2003 \\
\end{array}$ & $\begin{array}{l}\text { Cum. } \\
2002 \\
\end{array}$ & $\begin{array}{l}\text { Cum. } \\
2003 \\
\end{array}$ & $\begin{array}{l}\text { Cum. } \\
2002 \\
\end{array}$ & $\begin{array}{l}\text { Cum. } \\
2003\end{array}$ & $\begin{array}{l}\text { Cum. } \\
2002 \\
\end{array}$ & \\
\hline UNITED STATES & 682 & 728 & 23 & 48 & 474 & 981 & 20 & 32 & 1,677 \\
\hline $\begin{array}{l}\text { NEW ENGLAND } \\
\text { Maine }\end{array}$ & 20 & 9 & - & - & 14 & $\begin{array}{r}34 \\
2\end{array}$ & 1 & 4 & $\begin{array}{l}405 \\
211\end{array}$ \\
\hline N.H. & - & - & - & - & - & 1 & - & - & \\
\hline Vt. & - & - & - & - & - & - & - & - & 156 \\
\hline Mass. & 17 & 6 & - & - & 5 & 4 & - & 3 & 38 \\
\hline R.I. & 3 & - & - & - & 3 & 12 & - & - & - \\
\hline Conn. & - & 3 & - & - & 6 & 15 & 1 & 1 & - \\
\hline MID. ATLANTIC & 73 & 74 & 5 & 9 & 130 & 165 & 7 & 4 & - \\
\hline Upstate N.Y. & 3 & 3 & 3 & 1 & 1 & 14 & - & - & - \\
\hline N.Y. City & 46 & 42 & 1 & 3 & 117 & 75 & 7 & 2 & - \\
\hline N.J. & 23 & 19 & 1 & 5 & - & 41 & - & 2 & - \\
\hline $\mathrm{Pa}$ & 1 & 10 & - & - & 12 & 35 & - & - & - \\
\hline E.N. CENTRAL & 94 & 141 & 6 & 4 & 76 & 86 & 2 & 4 & 933 \\
\hline Ohio & 26 & 19 & 1 & - & 13 & 13 & - & 2 & 255 \\
\hline Ind. & 1 & 9 & 1 & - & 13 & 12 & 1 & - & - \\
\hline III. & 11 & 43 & 3 & 3 & 33 & 44 & - & - & - \\
\hline Mich. & 54 & 65 & 1 & 1 & 14 & 11 & 1 & 1 & 662 \\
\hline Wis. & 2 & 5 & - & - & 3 & 6 & - & 1 & 16 \\
\hline W.N. CENTRAL & 14 & 11 & - & - & 39 & 58 & - & 1 & 2 \\
\hline Minn. & 4 & 5 & - & - & 11 & 22 & - & 1 & - \\
\hline lowa & - & - & - & - & 6 & - & - & - & - \\
\hline & 3 & 3 & - & - & 8 & 24 & - & - & - \\
\hline N. Dak. & - & - & - & - & - & - & - & - & 2 \\
\hline S. Dak. & - & - & - & - & 4 & - & - & - & - \\
\hline Nebr. & - & 2 & - & - & & 1 & - & - & - \\
\hline Kans. & 7 & 1 & - & - & 10 & 11 & - & - & - \\
\hline S. ATLANTIC & 192 & 169 & 3 & 11 & 59 & 130 & 1 & 9 & 326 \\
\hline Del. & 1 & 2 & - & - & - & - & - & - & 1 \\
\hline & 30 & 14 & - & 1 & 8 & 10 & 1 & 1 & - \\
\hline & 5 & 3 & - & - & - & - & - & - & - \\
\hline Va. & 10 & 5 & - & - & 13 & 19 & - & - & 65 \\
\hline W.Va. & & - & - & - & 1 & 5 & - & - & 255 \\
\hline N.C. & 22 & 48 & - & 3 & 13 & 10 & - & - & - \\
\hline S.C. & 14 & 17 & 1 & 2 & 10 & 2 & - & - & 5 \\
\hline Ga. & 22 & 22 & - & 2 & 14 & 17 & - & 4 & - \\
\hline Fla. & 88 & 58 & 2 & 3 & - & 67 & - & 4 & - \\
\hline E.S. CENTRAL & 43 & 81 & 3 & 3 & 31 & 64 & - & - & - \\
\hline & 5 & 2 & - & - & - & 13 & - & - & - \\
\hline Tenn. & 21 & 33 & 3 & 2 & 9 & 29 & - & - & - \\
\hline Ala. & 14 & 31 & - & - & 22 & 16 & - & - & - \\
\hline Miss. & 3 & 15 & - & 1 & - & 6 & - & - & - \\
\hline W.S. CENTRAL & 96 & 100 & 2 & 16 & 12 & 206 & - & 3 & 1 \\
\hline & 8 & 1 & - & - & 5 & 3 & - & - & - \\
\hline La. & 11 & 20 & - & - & - & - & - & - & 1 \\
\hline Okla. & 6 & 11 & - & - & 7 & 2 & - & - & - \\
\hline Tex. & 71 & 68 & 2 & 16 & - & 201 & - & 3 & - \\
\hline MOUNTAIN & 22 & 36 & 4 & 2 & 10 & 31 & 2 & 1 & 10 \\
\hline Mont. & - & - & - & - & - & - & - & - & - \\
\hline Idaho & - & 1 & - & - & - & - & - & - & - \\
\hline Wyo. & - & - & - & - & 1 & 1 & - & - & 2 \\
\hline Colo. & - & 2 & - & 1 & 2 & 7 & 2 & 1 & - \\
\hline N. Mex. & 3 & 4 & - & - & - & 7 & - & - & - \\
\hline Ariz. & 19 & 29 & 4 & 1 & 7 & 11 & - & - & - \\
\hline Utah & - & - & - & - & - & 2 & - & - & 8 \\
\hline Nev. & - & - & - & - & - & 3 & - & - & - \\
\hline PACIFIC & 128 & 107 & - & 3 & 103 & 207 & 7 & 6 & - \\
\hline Wash. & 7 & 6 & - & - & 24 & 18 & - & - & - \\
\hline Oreg. & 5 & 4 & - & - & 6 & 8 & 2 & 1 & - \\
\hline Calif. & 114 & 96 & - & 3 & 49 & 154 & 5 & 5 & - \\
\hline Alaska & - & - & - & - & 9 & 11 & - & - & - \\
\hline Hawaii & 2 & 1 & - & - & 15 & 16 & - & - & - \\
\hline Guam & - & - & - & - & - & - & - & - & - \\
\hline & 9 & 23 & - & 8 & - & - & - & - & 5 \\
\hline V.I. & - & 1 & - & - & - & - & - & - & - \\
\hline Amer. Samoa & U & U & U & U & u & U & U & U & $U$ \\
\hline C.N.M.I. & - & $U$ & - & U & - & $U$ & - & U & - \\
\hline
\end{tabular}

$\mathrm{N}$ : Not notifiable. 
TABLE III. Deaths in 122 U.S. cities, ${ }^{\star}$ week ending February 15, 2003 (7th Week)

\begin{tabular}{|c|c|c|c|c|c|c|c|c|c|c|c|c|c|c|c|}
\hline \multirow[b]{2}{*}{ Reporting Area } & \multicolumn{6}{|c|}{ All causes, by age (years) } & \multirow[b]{2}{*}{$\begin{array}{l}\text { P\& }\left.\right|^{\dagger} \\
\text { Total }\end{array}$} & \multirow[b]{2}{*}{ Reporting Area } & \multicolumn{6}{|c|}{ All causes, by age (years) } & \multirow[b]{2}{*}{$\begin{array}{l}\text { P\&I }{ }^{\dagger} \\
\text { Total }\end{array}$} \\
\hline & $\begin{array}{c}\text { All } \\
\text { Ages }\end{array}$ & $\geq 65$ & $45-64$ & $25-44$ & $1-24$ & $<1$ & & & $\begin{array}{c}\text { All } \\
\text { Ages }\end{array}$ & $\geq 65$ & $45-64$ & $25-44$ & $1-24$ & $<1$ & \\
\hline NEW ENGLAND & 491 & 383 & 76 & 15 & 7 & 10 & 55 & S. ATLANTIC & 1,276 & 820 & 286 & 113 & 26 & 30 & 84 \\
\hline Boston, Mass. & 169 & 124 & 30 & 5 & 2 & 8 & 14 & Atlanta, Ga. & 203 & 124 & 50 & 23 & 5 & 1 & 11 \\
\hline Bridgeport, Conn. & 43 & 30 & 8 & 3 & 1 & 1 & 2 & Baltimore, Md. & 189 & 117 & 47 & 20 & 4 & 1 & 15 \\
\hline Cambridge, Mass. & 12 & 9 & 2 & 1 & - & - & 4 & Charlotte, N.C. & 119 & 83 & 17 & 13 & 3 & 3 & 7 \\
\hline Fall River, Mass. & 32 & 29 & 3 & - & - & - & 2 & Jacksonville, Fla. & 175 & 116 & 33 & 18 & 2 & 6 & 16 \\
\hline Hartford, Conn. & U & U & $\mathrm{U}$ & $U$ & $\mathrm{U}$ & U & $\mathrm{U}$ & Miami, Fla. & 124 & 76 & 33 & 8 & 2 & 5 & 8 \\
\hline Lowell, Mass. & 27 & 25 & 2 & - & - & - & 3 & Norfolk, Va. & 45 & 26 & 13 & 4 & 1 & 1 & 3 \\
\hline Lynn, Mass. & 15 & 11 & 4 & - & - & - & - & Richmond, Va. & 49 & 34 & 6 & 5 & 3 & 1 & 3 \\
\hline New Bedford, Mass. & 29 & 27 & 2 & - & - & - & 4 & Savannah, Ga. & 49 & 30 & 14 & 3 & 2 & - & 3 \\
\hline New Haven, Conn. & U & U & $\bar{U}$ & $U$ & $U$ & $U$ & U & St. Petersburg, Fla. & 77 & 50 & 17 & 6 & - & 3 & 3 \\
\hline Providence, R.I. & U & U & $U$ & U & $U$ & U & $U$ & Tampa, Fla. & 221 & 150 & 48 & 11 & 4 & 8 & 14 \\
\hline Somerville, Mass. & 5 & 4 & - & - & 1 & - & - & Washington, D.C. & U & U & U & U & U & $U$ & U \\
\hline Springfield, Mass. & 43 & 33 & 6 & 3 & 1 & - & 6 & Wilmington, Del. & 25 & 14 & 8 & 2 & - & 1 & 1 \\
\hline Waterbury, Conn. & 46 & 36 & 8 & 1 & 1 & - & 8 & E.S. CENTRAL & 888 & 617 & 174 & 58 & 27 & 11 & 73 \\
\hline Worcester, Mass. & 70 & 55 & 11 & 2 & 1 & 1 & 12 & Birmingham, Ala. & $\begin{array}{l}808 \\
198\end{array}$ & 140 & $\begin{array}{r}174 \\
36\end{array}$ & $\begin{array}{l}58 \\
16\end{array}$ & 3 & 2 & 22 \\
\hline MID. ATLANTIC & 2,270 & 1,582 & 468 & 124 & 38 & 54 & 130 & Chattanooga, Tenn. & 73 & 50 & 15 & 6 & 2 & - & 2 \\
\hline Albany, N.Y. & 48 & 37 & 8 & 2 & - & 1 & 2 & Knoxville, Tenn. & 106 & 81 & 18 & 4 & 1 & 2 & 5 \\
\hline Allentown, $\mathrm{Pa}$. & 23 & 19 & 4 & - & - & - & 1 & Lexington, Ky. & 69 & 47 & 17 & 3 & 2 & - & 9 \\
\hline Buffalo, N.Y. & 111 & 84 & 22 & 4 & - & 1 & 12 & Memphis, Tenn. & 171 & 117 & 34 & 12 & 5 & 3 & 11 \\
\hline Camden, N.J. & 43 & 26 & 9 & 6 & - & 2 & 8 & Mobile, Ala. & 87 & 59 & 17 & 6 & 3 & 2 & 10 \\
\hline Elizabeth, N.J. & U & U & $U$ & $U$ & $U$ & $U$ & $U$ & Montgomery, Ala. & 14 & 11 & 3 & - & - & - & 3 \\
\hline Erie, $\mathrm{Pa}$ & 58 & 49 & 6 & 1 & - & 2 & 2 & Nashville, Tenn. & 170 & 112 & 34 & 11 & 11 & 2 & 11 \\
\hline Jersey City, N.J. & 51 & 40 & 10 & 1 & - & - & - & WS CENTRAL & 1.130 & 731 & 220 & 83 & 52 & 44 & 79 \\
\hline New York City, N.Y. & 1,050 & 715 & 240 & 61 & 18 & 12 & 44 & $\begin{array}{l}\text { Austin, Tex. } \\
\text { A.S. }\end{array}$ & 104 & 63 & $\begin{array}{r}220 \\
27\end{array}$ & $\begin{array}{r}03 \\
9\end{array}$ & $\begin{array}{r}3 \\
2\end{array}$ & $\begin{array}{r}44 \\
3\end{array}$ & $\begin{array}{l}79 \\
13\end{array}$ \\
\hline Newark, N.J. & 49 & 16 & 15 & 11 & - & 7 & 1 & $\begin{array}{l}\text { Austin, lex. } \\
\text { Baton Rouge, La. }\end{array}$ & 66 & 40 & 18 & 4 & 1 & 3 & $\begin{array}{r}10 \\
1\end{array}$ \\
\hline Paterson, N.J. & 23 & 16 & 5 & - & 2 & - & 1 & $\begin{array}{l}\text { Baton Rouge, La. } \\
\text { Corpus Christi, Tex. }\end{array}$ & 59 & 43 & 9 & $\begin{array}{l}4 \\
3\end{array}$ & 1 & 3 & 4 \\
\hline Philadelphia, Pa. & 400 & 263 & 83 & 24 & 10 & 20 & 24 & $\begin{array}{l}\text { Corpus Christl, Iex. } \\
\text { Dallas, Tex. }\end{array}$ & $\begin{array}{l}59 \\
90\end{array}$ & $\begin{array}{l}40 \\
72\end{array}$ & 13 & 1 & 1 & 3 & $\begin{array}{l}4 \\
9\end{array}$ \\
\hline Pittsburgh, $\mathrm{Pa} .^{\S}$ & 29 & 20 & 6 & 1 & - & 2 & 1 & $\begin{array}{l}\text { Dallas, Iex. } \\
\text { EIPaso, Tex }\end{array}$ & 110 & 86 & $\begin{array}{l}13 \\
14\end{array}$ & 4 & 2 & 4 & $\begin{array}{l}y \\
1\end{array}$ \\
\hline Reading, $\mathrm{Pa}$. & 19 & 17 & 1 & 1 & - & - & - & Et Worth Tex. & 125 & $\begin{array}{l}80 \\
81\end{array}$ & $\begin{array}{l}14 \\
27\end{array}$ & $\begin{array}{r}4 \\
12\end{array}$ & 2 & $\begin{array}{l}4 \\
3\end{array}$ & $\begin{array}{r}1 \\
12\end{array}$ \\
\hline Rochester, N.Y. & 133 & 103 & 24 & 3 & 1 & 2 & 13 & Ft. Worth, lex. & $\begin{array}{l}1<0 \\
369\end{array}$ & 204 & $\begin{array}{l}27 \\
74\end{array}$ & $\begin{array}{l}12 \\
35\end{array}$ & 37 & $\begin{array}{r}3 \\
19\end{array}$ & $\begin{array}{l}12 \\
24\end{array}$ \\
\hline Schenectady, N.Y. & 18 & 15 & 2 & - & 1 & - & 1 & Little Rock Ark & $\begin{array}{r}309 \\
67\end{array}$ & $\begin{array}{r}<4 \\
39\end{array}$ & $\begin{array}{l}14 \\
13\end{array}$ & $\begin{array}{r}35 \\
8\end{array}$ & $\begin{array}{r}31 \\
3\end{array}$ & 19 & 24 \\
\hline Scranton, Pa. & 31 & 25 & 5 & 1 & - & - & 2 & LItIe Rock, AIK. & $6 /$ & 39 & U & 8 & 3 & $\begin{array}{c}4 \\
U\end{array}$ & $\bar{u}$ \\
\hline Syracuse, N.Y. & 101 & 78 & 14 & 4 & 3 & 2 & 12 & New Urleans, La. & U & U & U & U & U & U & U \\
\hline Trenton, N.J. & 37 & 26 & 5 & 2 & 1 & 3 & - & San Antonio, lex. & 38 & 29 & 7 & 1 & U & 1 & U \\
\hline Utica, N.Y. & 15 & 8 & 5 & 1 & 1 & - & 1 & Shreveport, La. & $\begin{array}{r}38 \\
102\end{array}$ & 29 & $\begin{array}{r}7 \\
18\end{array}$ & 1 & $\overline{3}$ & $\begin{array}{l}1 \\
1\end{array}$ & $\begin{array}{r}5 \\
10\end{array}$ \\
\hline Yonkers, N.Y. & 31 & 25 & 4 & 1 & 1 & - & 5 & Tulsa, Okla. & 102 & 74 & 18 & 6 & 3 & 1 & 10 \\
\hline E.N. CENTRAL & 1,967 & 1,321 & 429 & 124 & 55 & 38 & 143 & MOUNTAIN & 931 & 602 & 159 & 87 & 38 & 26 & 59 \\
\hline Akron, Ohio & 58 & 36 & 13 & 5 & 3 & 1 & 10 & Albuquerque, N.M. & 123 & 73 & - & 30 & 18 & 2 & 7 \\
\hline Canton, Ohio & 45 & 32 & 10 & 2 & 1 & - & 4 & Boise, Idaho & 42 & 33 & 7 & - & 2 & - & 6 \\
\hline Chicago, III. & 318 & 192 & 89 & 29 & 4 & 4 & 26 & Colo. Springs, Colo. & 64 & 39 & 4 & 2 & - & - & 1 \\
\hline Cincinnati, Ohio & 99 & 71 & 18 & 4 & 1 & $\begin{array}{l}4 \\
5\end{array}$ & 12 & Denver, Colo. & 111 & 65 & 21 & 9 & 8 & 8 & 10 \\
\hline Cleveland, Ohio & 148 & 96 & 37 & $\begin{array}{l}4 \\
8\end{array}$ & 4 & 3 & 4 & Las Vegas, Nev. & 261 & 159 & 72 & 21 & 5 & 4 & 13 \\
\hline Columbus, Ohio & 210 & 136 & 48 & 16 & $\begin{array}{l}4 \\
5\end{array}$ & 5 & 22 & Ogden, Utah & 26 & 20 & 3 & 3 & - & - & 2 \\
\hline Dayton, Ohio & 118 & 80 & 23 & 6 & 8 & 1 & $\begin{array}{r}22 \\
4\end{array}$ & Phoenix, Ariz. & U & U & $\mathrm{U}$ & $U$ & U & $U$ & $U$ \\
\hline Detroit, Mich. & 187 & 106 & 49 & 12 & 11 & 9 & 10 & Pueblo, Colo. & 23 & 19 & 2 & 2 & - & - & 3 \\
\hline Evansville, Ind. & 42 & 42 & - & - & - & - & 3 & Salt Lake City, Utah & 94 & 55 & 20 & 10 & 2 & 7 & 8 \\
\hline Fort Wayne, Ind. & 59 & 42 & 8 & 8 & 1 & - & 3 & Tucson, Ariz. & 187 & 139 & 30 & 10 & 3 & 5 & 9 \\
\hline Gary, Ind. & 14 & 8 & 2 & 3 & 1 & - & - & PACIFIC & 1,629 & 1,134 & 314 & 100 & 42 & 34 & 148 \\
\hline Grand Rapids, Mich. & 55 & 41 & 11 & 2 & - & 1 & 7 & Berkeley, Calif. & 12 & 8 & 4 & - & - & - & 1 \\
\hline Indianapolis, Ind. & 241 & 163 & 56 & 13 & 5 & 4 & 12 & Fresno, Calif. & 155 & 111 & 28 & 12 & 4 & - & 9 \\
\hline Lansing, Mich. & U & U & U & $U$ & $U$ & U & $U$ & Glendale, Calif. & 20 & 17 & 2 & 1 & - & - & 2 \\
\hline Milwaukee, Wis. & 122 & 88 & 21 & 6 & 6 & 1 & 12 & Honolulu, Hawaii & U & U & $U$ & $U$ & U & $\mathrm{U}$ & U \\
\hline Peoria, III. & 44 & 36 & 6 & 2 & - & - & 2 & Long Beach, Calif. & 58 & 35 & 13 & 5 & 3 & 2 & 10 \\
\hline Rockford, III. & 64 & 51 & 9 & 2 & 2 & - & 6 & Los Angeles, Calif. & 425 & 285 & 85 & 31 & 16 & 8 & 37 \\
\hline South Bend, Ind. & 50 & 31 & 13 & 1 & 3 & 2 & 1 & Pasadena, Calif. & 27 & 18 & 2 & 1 & - & 1 & 2 \\
\hline Toledo, Ohio & 93 & 70 & 16 & 5 & - & 2 & 5 & Portland, Oreg. & 121 & 82 & 28 & 6 & 3 & 2 & 5 \\
\hline Youngstown, Ohio & U & U & U & $U$ & $U$ & $\bar{U}$ & $U$ & Sacramento, Calif. & 155 & 112 & 27 & 11 & 2 & 3 & 20 \\
\hline W.N. CENTRAL & 564 & 395 & 104 & 34 & 19 & 12 & 38 & San Diego, Calif. & 166 & 111 & 33 & 11 & 3 & 8 & 17 \\
\hline Des Moines, lowa & $\begin{array}{r}504 \\
48\end{array}$ & 42 & 4 & $\begin{array}{r}34 \\
1\end{array}$ & 1 & 12 & $\begin{array}{r}50 \\
3\end{array}$ & San Francisco, Calif. & U & U & U & U & $\mathrm{U}$ & $\mathrm{U}$ & U \\
\hline Duluth, Minn. & $\begin{array}{l}40 \\
34\end{array}$ & $\begin{array}{l}42 \\
25\end{array}$ & 8 & 1 & - & - & 3 & San Jose, Calif. & 197 & 142 & 34 & 11 & 4 & 6 & 25 \\
\hline Kansas City, Kans. & 47 & 24 & 15 & 4 & 3 & 1 & 3 & Santa Cruz, Calif. & 28 & 22 & 4 & 1 & 1 & - & 3 \\
\hline Kansas City, Mo. & 100 & 66 & 18 & 8 & 6 & 2 & 6 & Seattle, Wash. & 90 & 61 & 19 & 6 & 3 & 1 & 6 \\
\hline Lincoln, Nebr. & 35 & 26 & 4 & 3 & - & 2 & 5 & Spokane, Wash. & 65 & 51 & 11 & - & 1 & 2 & 4 \\
\hline Minneapolis, Minn. & 71 & 47 & 13 & 2 & 5 & 4 & 5 & Tacoma, Wash. & 110 & 79 & 24 & 4 & 2 & 1 & 7 \\
\hline Omaha, Nebr. & 98 & 74 & 11 & 7 & 4 & 2 & 6 & TOTAL & 11,146 & 7,585 & 2,230 & 738 & 304 & 259 & 809 \\
\hline St. Louis, Mo. & U & U & U & U & $U$ & $\bar{U}$ & $U$ & & & & & & & & \\
\hline St. Paul, Minn. & 47 & 37 & 8 & 1 & - & 1 & 3 & & & & & & & & \\
\hline Wichita, Kans. & 84 & 54 & 23 & 7 & - & - & 6 & & & & & & & & \\
\hline
\end{tabular}

\section{U: Unavailable. -:No reported cases.}

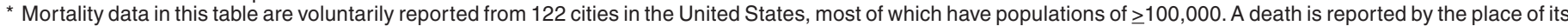
occurrence and by the week that the death certificate was filed. Fetal deaths are not included.

† Pneumonia and influenza.

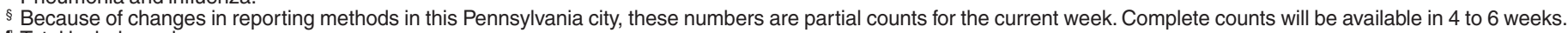

ๆ Total includes unknown ages. 
All $M M W R$ references are available on the Internet at http://www.cdc.gov/mmwr. Use the search function to find specific articles.

Use of trade names and commercial sources is for identification only and does not imply endorsement by the U.S. Department of Health and Human Services.

References to non-CDC sites on the Internet are provided as a service to $M M W R$ readers and do not constitute or imply endorsement of these organizations or their programs by CDC or the U.S. Department of Health and Human Services. CDC is not responsible for the content of these sites. URL addresses listed in $M M W R$ were current as of the date of publication. 
The Morbidity and Mortality Weekly Report (MMWR) Series is prepared by the Centers for Disease Control and Prevention (CDC) and is available free of charge in electronic format and on a paid subscription basis for paper copy. To receive an electronic copy each week, send an e-mail message to listserv@listserv.cdc.gov. The body content should read SUBscribe mmwr-toc. Electronic copy also is available from CDC's World-Wide Web server at http://www.cdc.gov/mmwr or from CDC's file transfer protocol server at ftp://ftp.cdc.gov/pub/publications/ mmwr. To subscribe for paper copy, contact Superintendent of Documents, U.S. Government Printing Office, Washington, DC 20402; telephone 202-512-1800.

Data in the weekly $M M W R$ are provisional, based on weekly reports to CDC by state health departments. The reporting week concludes at close of business on Friday; compiled data on a national basis are officially released to the public on the following Friday. Address inquiries about the $M M W R$ Series, including material to be considered for publication, to Editor, $M M W R$ Series, Mailstop C-08, CDC, 1600 Clifton Rd., N.E., Atlanta, GA 30333; telephone 888-232-3228.

All material in the MMWR Series is in the public domain and may be used and reprinted without permission; citation as to source, however, is appreciated.

放U.S. Government Printing Office: 2003-533-155/69096 Region IV 